Article

\title{
Simulating Changes in Fires and Ecology of the 21st Century Eurasian Boreal Forests of Siberia
}

\author{
Ksenia Brazhnik *, Charles Hanley and Herman H. Shugart \\ Environmental Sciences Department, University of Virginia, 291 McCormick Road, \\ Charlottesville, VA 22904-4123, USA; csh7rm@virginia.edu (C.H.); hhs@virginia.edu (H.H.S.) \\ * Correspondence: ksenia@virginia.edu; Tel.: +1-540-745-4117
}

Academic Editors: Annika Nordin and Tomas Lundmark

Received: 10 November 2016; Accepted: 15 February 2017; Published: 21 February 2017

\begin{abstract}
Wildfires release the greatest amount of carbon into the atmosphere compared to other forest disturbances. To understand how current and potential future fire regimes may affect the role of the Eurasian boreal forest in the global carbon cycle, we employed a new, spatially-explicit fire module DISTURB-F (DISTURBance-Fire) in tandem with a spatially-explicit, individually-based gap dynamics model SIBBORK (SIBerian BOReal forest simulator calibrated to Krasnoyarsk Region). DISTURB-F simulates the effect of forest fire on the boreal ecosystem, namely the mortality of all or only the susceptible trees (loss of biomass, i.e., carbon) within the forested landscape. The fire module captures some important feedbacks between climate, fire and vegetation structure. We investigated the potential climate-driven changes in the fire regime and vegetation in middle and south taiga in central Siberia, a region with extensive boreal forest and rapidly changing climate. The output from this coupled simulation can be used to estimate carbon losses from the ecosystem as a result of fires of different sizes and intensities over the course of secondary succession (decades to centuries). Furthermore, it may be used to assess the post-fire carbon storage capacity of potential future forests, the structure and composition of which may differ significantly from current Eurasian boreal forests due to regeneration under a different climate.
\end{abstract}

Keywords: boreal forest; carbon; climate change; fire; SIBBORK; Siberia; simulation model; spatially-explicit; taiga

\section{Introduction}

Chapin et al. [1] define a "disturbance" as a period of time during which the ecosystem loses carbon. Over the timeframe of centuries to millennia, forest ecosystems, disturbance regimes and atmospheric carbon concentrations acquire a steady state, within which the carbon losses from the ecosystem are balanced by the carbon sequestered and stored by the ecosystem [2]. Changes in any component of the system disturb this steady state, such as with the current increase in disturbance frequency, extent and severity within the global boreal forests, and can result in increased carbon release to the atmosphere and decreased storage capacity in the terrestrial biosphere [3]. The current rate of change in the disturbance regimes is too fast to achieve a carbon balance through forest regeneration, because succession occurs over the course of multiple decades to centuries. In order to understand how the boreal ecosystem may be contributing to the global carbon budget in the near future, it is important to estimate how far from the steady state this system is being displaced by the changes in the fire regime and the associated biomass losses from these forests.

Fire is the most prominent stand-replacing disturbance in the boreal ecosystem [4,5]. Millions of hectares of boreal vegetation are destroyed by wildfires annually [6]. Wildfires affect an ecosystem through a multitude of processes, including a large initial carbon pulse to the atmosphere, decreased surface and (charred) vegetation albedo in the short term (years; [7]), followed by increased albedo 
in the long term (decades; [8]), an increase in forest floor decomposition rates and the availability of soil nutrients or loss of forest floor, increased amount of light reaching the ground, as well as modified hydrology and radiation budgets [9,10]. The wildfire pattern in boreal forests is an important driving factor in the landscape-scale stand structure and diversity in those ecosystems $[4,11,12]$. As fire removes living biomass from the forest and affects regeneration, growth and mortality processes, modeling the effect of fires on a forest provides insight into the role of the forest in the global carbon budget, which inevitably depends on forest structure and composition. Feedbacks between the forest ecosystem and the fire regime include the effect of forest type on the probability and intensity of fire, as well as the effect of fire on forest structure, composition and regeneration trajectory. These feedbacks may change or intensify as climate alters both the forest structure and the characteristics of the fire regime within the boreal ecotone. Our investigation complements Conard and Ivanova's [3] call for better estimates of fire effects on the carbon storage, carbon emissions, as well as structure and composition of boreal forests under current and changing fire regimes and climatological conditions.

Forest Structure: Wildfires can occur in a forest of any age, structure and composition. Ignition is often facilitated by lightning [13], although over $80 \%$ of fires in Siberia are likely anthropogenic in origin [14-17]. Sources of ignition are increasing due to an increase in both the lightning storms and forest use [18]. The amount of fuel load, topography and the wind conditions determine the mean fire return interval, intensity and rate of spread $[12,17,19]$. Climatic changes affect the amount of moisture in vegetation and, therefore, the likelihood of ignition [20]. As ambient temperatures warm, but no significant changes in precipitation are observed in some regions of Siberia [21,22], more prolonged dry periods are occurring across central and southern Siberia [23], which stress vegetation, prepare the fuel load and facilitate ignitions and fire spread. Additionally, forest composition can also facilitate or suppress the development of crown fires. For example, high crown moisture content in broadleaf and larch canopies can suppress crown fire development, while drought-stressed highly flammable dark conifer needles facilitate crown fires $[5,24,25]$ and mediate, to an extent, the amount of carbon released to the atmosphere [8]. It is difficult to include all influencing factors in a numerical model of fire, climate and vegetation, so for the purpose of simplification, we focus on vegetation characteristics and soil moisture, the latter of which is most directly correlated with the fire regime [12]. Forest structure and composition and the level of drought-stress in vegetation are, therefore, primary considerations in our fire module DISTURB-F.

Fire Intensity: The effect of fire on forest vegetation depends on fire intensity. Wildfires are often classified into two categories based on intensity: crown (high intensity) and ground (low intensity) [26]. Ground fires represent the vast majority of fires reported in Eurasia and are most common in pine and larch forests [5,6]. This type of fire destroys susceptible tree species (dark conifers), as well as the understory and promotes forests comprised of resistor species (e.g., pine and larch; Table 1, [4,27]). Conversely, crown fires are intense enough to kill all vegetation $[28,29]$ and are more commonly observed in dark conifer forests $[5,12]$. There is significant interannual variability in the area burned each year and the degree of damage to the forest stands [6,30]; however, there appears to be a correlation between years with a greater portion of the growing season in drought and the extent of fire damage [1], as well as a greater number of crown fires. During average years, as much as $80 \%$ of the burned area in Eurasian boreal forests may experience low-intensity surface fires, while in intense fire years, up to $50 \%$ of the burned area may suffer high-intensity crown fires $[6,14,17,29,31,32]$. Furthermore, different arboreal species have different tolerances to fires: pines and larches are able to survive most low-severity ground fires due to thicker bark [26], while aspen and birch experience complete mortality [5]. In areas that have experienced high-intensity crown fires, regenerating vegetation is more biodiverse, compared to regeneration following ground fires [4]. In this manner, the frequency of crown fires has a significant effect on long-term forest dynamics and carbon budget. 
Table 1. Fire tolerance is used to determine which species survive a ground fire. All trees are assumed to die in a crown fire.

\begin{tabular}{cccc}
\hline Species & Abbreviation & Fire Tolerance (Code) & Fire Plant Functional Type \\
\hline Abies sibirica & ABSI & intolerant (0) & avoider \\
Larix sibirica & LASI & very tolerant (1) & resister \\
Betula pendula & BEPE (Betula spp.) & somewhat intolerant $(0)$ & invader \\
Picea obovata & PIOB & intolerant (0) & avoider \\
Pinus sibirica & PISI & intolerant (0) & avoider \\
Pinus sylvestris & PISY & tolerant (1) & resister \\
Populus tremula & POTR (Populus spp.) & intolerant $(0)$ & endurer \\
\hline
\end{tabular}

Fire Size: The size of the forest fire not only affects the amount of carbon released into the atmosphere, but also the landscape pattern and the type of vegetation that is likely to regenerate within the burned area. Post-fire regeneration determines the ability of the ecosystem to recover carbon following the disturbance. Forests subject to fires less than 50 ha in size are often replaced by the same species that grew in the area pre-fire, whereas following larger fires, regeneration is delayed, but all species whose range overlaps the burned area are likely to be represented in the new growth [33]. Simulation of fire effects using a vegetation model that simulates independent plots, i.e., Monte Carlo simulation, is not able to capture fires of different sizes due to the lack of spatial complexity. Furthermore, although probabilistic fire subroutines have been coupled with simulations of independent plots, in this combination, the disturbance affects one plot at a time, and the largest gap simulated following a disturbance is only the size of one plot, so the effects of the created gap on the surrounding forest are not captured. SIBBORK coupled with DISTURB-F, however, can be operated in independent and spatially-explicit modes. The latter allows for the simulation of fires of different extents (multiple adjacent plots), resulting in different light geometry within gaps of different sizes, which affects the regeneration that occurs within the created gaps and on nearby plots. Although the independent plot mode can be used to estimate the average biomass or carbon loss on the landscape due to fire, the spatially-explicit mode captures the spatial patterns of disturbance on the landscape, including the release of vegetation (increase in annual diameter at breast height (DBH) increment) on plots near the disturbance-generated gaps.

Changing Climate: The nature of post-fire vegetation recovery may differ significantly from the successional pathway that resulted in the pre-burn forest structure and composition [12], especially if it occurs under different climatological conditions $[8,20,29,33-36]$. The pre- and post-burn vegetation composition and structure affect the surface biophysics, including the regional albedo and the role of the region in the global carbon budget [3,37]. Ambient temperatures over Russia have been increasing at 2.5-times the global rate [22]. Rapid climatological changes have been observed across Siberia since 1990, especially in the mountainous terrain of southern Siberia, to the west and south of Lake Baikal [22]. Warming temperatures not accompanied by appreciable precipitation changes have been altering the structure and composition of existing forests through stress-induced mortality [38,39]. The regeneration process of forests post disturbance events, such as wildfire, is also likely to be different under warmer, drier conditions and may even lead to biome shifts, potentially increasing the fire danger in the region (such as with a shift from forest to steppe) and decreasing carbon storage (biomass). In this manner, climate change has direct and indirect effects on forest structure and composition through effects on physiological processes and disturbance regimes.

Population pressures and recent climatological shifts have been influencing the fire regimes across the globe. Fire in Eurasian boreal forests already has a longer season than other circumpolar boreal ecosystems by several months $[1,5]$ and has been expanding in recent decades [22]. The extent of fire-affected areas in boreal forest can be upwards of 20 million hectares of vegetation in a single extreme fire year [1] and has nearly doubled between 1970 and 1990 [14]. In recent decades, likely due to increasing disturbances, the loss of forest biomass has exceeded biomass accumulation in 
these forests [40-42]. Canadian boreal forests are already experiencing greater loss of biomass to timber harvest, stress-induced stand mortality, insect outbreaks, fires and other disturbances than accumulation of live biomass [43-45]. In order to understand the near-future carbon balance of the Siberian boreal ecosystem, we applied the fire disturbance module DISTURB-F coupled with the spatially-explicit gap dynamics model SIBBORK under historical and potential future climatic conditions.

Spatially-Explicit Simulation of Gap Dynamics: SIBBORK is an Individual-Based gap dynamics Model (IBM) that keeps track of the establishment, growth, stress and mortality of millions of trees on a user-generated or Digital Elevation Model (DEM)-based three-dimensional landscape (details in [46]). This is a spatially-explicit model, in which trees experience different environmental conditions based on their position on the landscape and within the canopy. SIBBORK simulates carbon allocation to tree biomass, but does not keep track of carbon pools in the organic forest floor or atmospheric carbon concentrations. SIBBORK has been calibrated to the southern taiga ecotone in central Siberia and has been validated against multidimensional datasets from southern, middle and northern taiga locations, including the mountainous region near the southernmost extent of the boreal forest $[46,47]$. To date, it is the only individual-based vegetation model that has been able to accurately simulate the distribution of expositional forest steppe in the mountains of southern Siberia, based on accurate simulation of environmental conditions on the specified landscape. As climate is changing heterogeneously in space and time and fire occurrences are influenced by local conditions, the ability of SIBBORK to simulate the locations on the landscape that experience drought or are populated by stressed vegetation lends itself to coupling with a fire module that is triggered by local environmental and vegetation conditions. The spatially-explicit simulation environment allows for specification of different fire return intervals and likely intensities for different locations within the same simulation. Inclusion of disturbance in the simulation, an event that affects the stress level and mortality of multiple individuals within one year, is likely to shift the forest structure toward a younger forest, and forest composition, toward greater prevalence of pioneer species [8] and lower biomass (carbon storage). Repeat disturbances may also result in non-reversible biome shifts (e.g., forest to steppe). For example, in the simulation of the Siberian boreal forest with more frequent disturbances, dense stands of birch and aspen may become more prominent, and transition to a dark conifer forest may not be reached between disturbances [12,48,49], or tree vegetation may no longer regenerate under certain environmental conditions. As SIBBORK is able to capture the heterogeneous response of vegetation to the conditions on the landscape, it presents a robust platform for investigating current and potential near-future land-cover change dynamics in the Siberian boreal forest, including changes due to fire disturbances. The tandem SIBBORK-DISTURB-F platform can also be easily re-parameterized to other forest ecosystems and fire regimes.

\section{Experimental Section}

The fire module DISTURB-F functions in two modes: probabilistic and drought-triggered. Fires are initiated probabilistically on each plot based on the specified Mean Fire Return Interval (MFRI) for the simulated landscape. The probability of a fire in a given year is the inverse of the MFRI. The specified MFRI in the simulation means that each plot has a chance of burning once every that many years. However, the MFRI can be vastly different in adjacent territories within a small region, e.g., south- and north-facing slopes in mountainous southern Siberia [50] (Table 2). Not only is there spatial heterogeneity in fire occurrences across the landscape, but there are spatial patterns with certain locations, hotspots, where fires occur with greater frequency [51]. In southern taiga, regeneration is particularly adversely affected on repeated burn sites [51]. Within the spatially-explicit SIBBORK simulation, DISTURB-F introduces a plot-level matrix that specifies the MFRI and, therefore, the fire probability, at the plot-level. Fire intensity is estimated based on observed average annual crown fire fraction: $20 \%$ are crown fires that result in total mortality on the plot, and $80 \%$ are ground fires $[3,4,31]$, which retain tolerant species in the canopy and remove susceptible species 
and undergrowth ( $\mathrm{DBH}<8 \mathrm{~cm}[48,52]$; $\mathrm{DBH}<6-20 \mathrm{~cm}$ [53]). Within the spatially-explicit simulation, the light geometry on each plot is affected by the structure of vegetation on surrounding plots. The subroutine is similar to the parameterization used for exogenous mortality in early gap dynamics models [54]. This approach is salient in its simplicity and allows for ease of validation against average percent of area burned reported for the different ecotones of Siberia (Table 3).

Table 2. Mean Fire Return Interval (MFRI) for north- and south-facing slopes in southern Siberia. We used MFRI of 40 years on the south-facing slopes and 200 years on the north-facing slopes. (PISY = Pinus sylvestris, LASI = Larix sibirica, $\mathrm{ABSI}=$ Abies sibirica, $\mathrm{PIOB}=$ Picea obovata ; see Table 1 for other species abbreviations).

\begin{tabular}{ccc}
\hline Reference & South-Facing Slope & North-Facing Slope \\
\hline Ivanova and Ivanov, 2005 [55] & $8-21$ years & - \\
Ivanova et al., 2010 [28] & $60-70$ (mixed PISY/LASI) & - \\
Wirth, 2005 [26] & 28 (PISY), 54 (LASI) & 150 (ABSI, PIOB), 265 \\
Sannikov and Goldammer, 1996 [49] & $5-50$ years & $30-50$ years \\
Furyaev, 1996 [12] & - & 300 \\
\hline
\end{tabular}

Table 3. Mean fire return interval (MFRI) varies by region and forest type. The shortest MFRI is found in pine stands and is approximately 10 years, while the longest MFRI in dark conifer stands can be upward of 640 years. Conard and Ivanova [3] suggest 50 years as a default average MFRI for Russian boreal forest when the exact MFRI for the ecotone is not known.

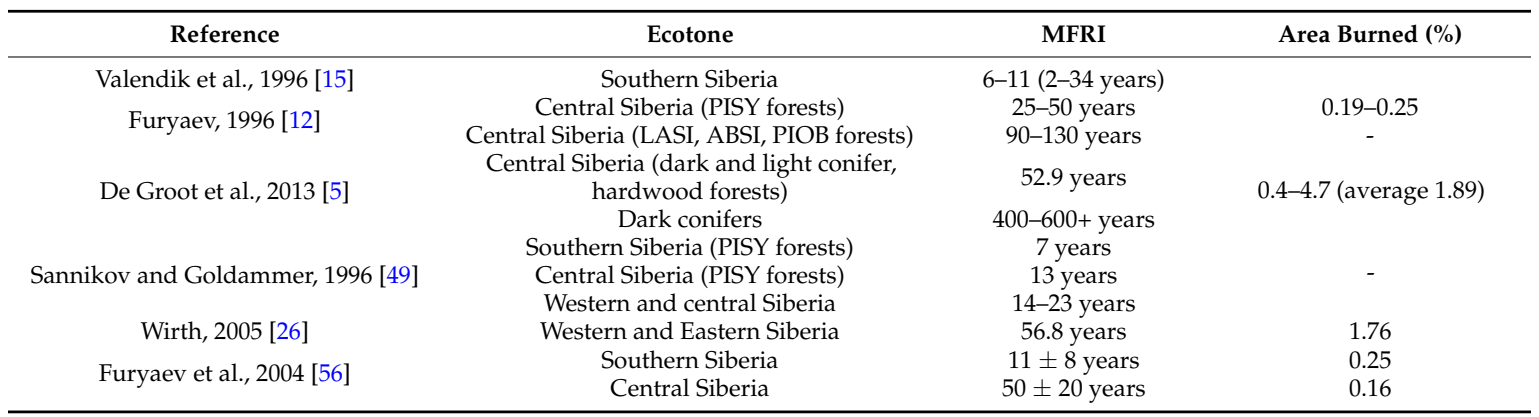

In the short term, Buryak and colleagues directly relate drought days to fire danger in southern Siberia [33], while in the long term, consecutive drought years enhance fire probability, extent and intensity [57]. Furthermore, Furyaev [12] suggests that soil moisture is most strongly correlated with the fire regime. For this reason, the drought-triggered mode includes input from the environmental conditions on each plot, namely the fraction of growing season in drought, which we defined as soil moisture below site- and soil-specific wilting point (see [46] for details). The dependence of fire probability on local environmental conditions couples the environmental conditions to the disturbance regime: drought occurs at different locations within the simulated landscape based on environmental conditions (precipitation, Potential Evapotranspiration (PET) demands, soil characteristics, etc.), and the probability of fire occurrence also varies across the terrain. Furthermore, fires triggered by drought have a higher probability of becoming a high intensity crown fire. Drought enhances the fire probability as shown in Equation (1), wherein a simple linear model is employed to induce additional fire events in years with a specified portion of the growing season in drought:

$$
\text { Fire probability }=\beta_{0}+\beta_{1} \times \text { DFRC }
$$

where $\beta_{0}$ represents the MFRI (years ${ }^{-1}$ ) and is specified at the plot level and $\beta_{1}$ represents the fraction of the growing season in drought. The Drought Fire Risk Coefficient (DFRC) was empirically estimated based on how much greater the observed area burned was during particularly dry years in each ecotone. The model was calibrated on 9-ha flat terrain simulation with climate and edaphic characteristics from 
central Siberia. Calibration involved iterative adjustment of the drought fire risk coefficient to best approximate the area burned during severe fire years in this region. No other tuning or calibration of model parameters was conducted.

The drought trigger is activated when the most drought-intolerant species is stressed, which corresponds to $10 \%$ of the growing season with soil moisture at or below wilting point. It is difficult to assess exactly how much drought enhances the fire probability, but there appears to be an order of magnitude difference in burn areas between average and severe fire years, the latter associated with drought [12]. In SIBBORK, tree species have different tolerances for drought stress, but even the most tolerant species are stressed when $40 \%$ or more of the growing season is in drought. For these reasons, if at least half of the growing season is in drought, the probability of fire is increased seven-fold that year. If less than half of the growing season is in drought, the increase in fire activity is between $1 \times$ and $7 \times$, based on the fraction of the season in drought [45]. In the simulation, drought triggers also increase the proportion of crown fires. Probability alone has a $20 \%$ chance of triggering a crown fire, whereas drought has a 50\% chance of triggering a crown fire. All trees on a plot die if a crown fire is triggered. However, if a ground fire occurs on a plot, all understory with a DBH of less than $8 \mathrm{~cm}$ (8-12 cm [52]; 6-20 cm [49]) and all trees of susceptible species die and are removed from the simulation. Fire tolerance is species-specific and is a Boolean parameter in the simulation (Table 1). The decision tree for this subroutine is shown in Figure 1. Fires are initiated only on plots that have trees, in order to more closely approximate observed forest fire statistics from the specific regions simulated. For example, in the forest-steppe ecotone, fire only ignites on plots with forest vegetation, and not on non-vegetated or non-forest plots, which represent alpine tundra or steppe. It is already known that the steppe has a more frequent fire return interval $[15,58]$.

To assess the DISTURB-F functionality and the ability of the coupled vegetation-fire model to produce forest stands with structure and composition similar to those observed in the field, as well as the observed annual fraction of area burned, we conducted two simulations: within middle taiga (Irkutsk Region) and southern taiga (Tuva Republic) ecotones. Simulation site selection was based on data availability regarding forest characteristics and fire regimes. However, the central Siberian site is representative of most of central Siberian middle taiga forest with regards to climate, topography, soils and type of forest and, in recent decades, has experienced an increase in the length of the fire season and intensification of the fire regime [59]. The southern taiga location represents an area where approximately $40 \%$ of annual fires in Russia occur [60]. It also represents a region of Siberia where shifts in vegetation type associated with climate change have already been observed [28] and the increase in frequency and intensity of fires is facilitating a non-reversible (on the human time scale) shift from forest to steppe or grassland [29,60]. Both sites are within the region likely to experience as much as 30\% increase in the drought index and fire risk by the end of the 21st century, with the greatest changes anticipated along the southern boundary of the boreal zone [61]. Site-specific soil characteristics were obtained from a georeferenced database [62]. Historical climate (1960-1990) and current temperature and precipitation trends (1990-2014) were obtained from the National Climate Data Center and the Russian Hydrometeorology Office [22,63,64]. Figure 2 shows the observed historical climatology (1960-1990) for the two sites, as well as recent observations (2008-2016) and estimated future temperature trends $[22,63,64]$. Interestingly, no significant changes have been observed in precipitation in Siberia [21,22], and a small decrease in precipitation has been observed in southern taiga, near the southern boundary of the boreal forest [65]. Topography, climate and edaphic conditions for both simulations are summarized in Table 4. 


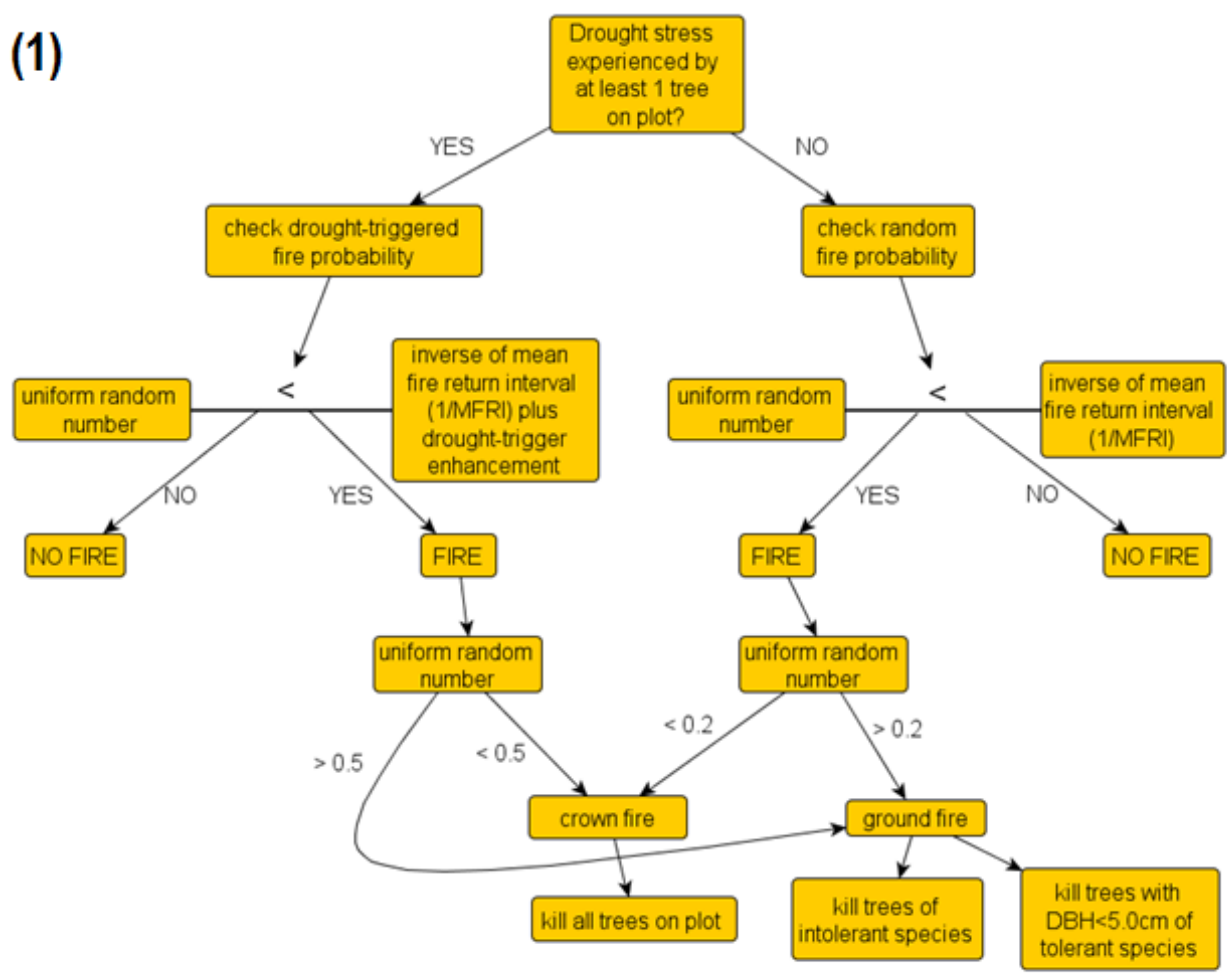

(2)

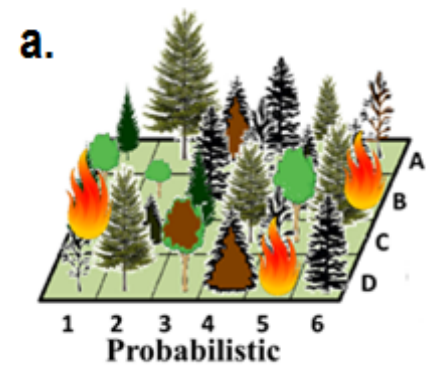

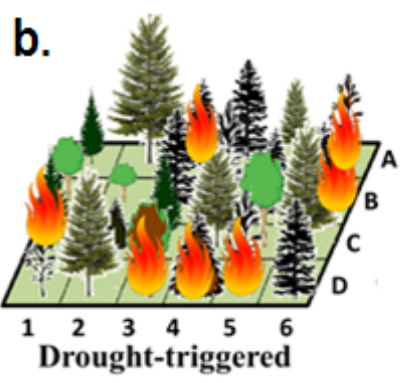

Figure 1. (1) Process flow for two DISTURB-F modes: based on mean annual probability and additionally based on a drought trigger fire killing all or only susceptible tree species in plots; (2) visualization of fire on a simulated grid of plots. (a): fires based on MFRI/probability on a simulated landscape; fire kills all or only susceptible tree species in plots B6, C1 and 5D; (b): fires based on probability and drought; results in mortality of all or only susceptible species, understory trees also burn, depending on fire intensity, as shown in drought-stressed plots A3, A6, D4 and D5, designated by brown trees here and on the left. 
Table 4. Environmental conditions at middle and southern taiga sites within the boreal forest in central Siberia. Top row: topographic, climatological and edaphic conditions near Severny leshoz; bottom row: topographic, climatological and edaphic conditions near Kyzyl, in Republic of Tyva, in southern Alay-Sayan mountain region.

\begin{tabular}{|c|c|c|c|c|c|c|c|c|c|c|c|c|}
\hline $\begin{array}{c}\text { Latitude, } \\
\text { Longitude, } \\
\text { Altitude (m) }\end{array}$ & Aspect & Slope & $\begin{array}{l}\text { Plot Size } \\
\left(\mathrm{m}^{2}\right)\end{array}$ & $\begin{array}{l}\text { Simulation } \\
\text { Domain } \\
\text { (Plots, ha) }\end{array}$ & $\begin{array}{l}\text { Dominant } \\
\text { Soil Type (s) }\end{array}$ & $\begin{array}{l}\text { Soil Field } \\
\text { Capacity } \\
\text { (cm) }\end{array}$ & $\begin{array}{l}\text { Soil Wilting } \\
\text { Point (cm) }\end{array}$ & $\begin{array}{c}\text { Mean } \\
\text { Monthly } \\
\text { Temperature } \\
\left({ }^{\circ} \mathrm{C}\right)\end{array}$ & $\begin{array}{c}\text { Mean } \\
\text { Monthly } \\
\text { Precipitation } \\
\text { (mm) }\end{array}$ & $\begin{array}{l}\text { Mean } \\
\text { Monthly } \\
\text { Radiation } \\
\left(\mathbf{W} \cdot \mathrm{m}^{-2}\right)\end{array}$ & $\begin{array}{l}\text { Mean Monthly } \\
\text { Radiation } \\
\text { (Growing } \\
\text { Season) }\left(\mathrm{W} \cdot \mathrm{m}^{-2} \text { ) }\right.\end{array}$ & $\begin{array}{l}\text { Relative Direct and } \\
\text { Diffuse Solar } \\
\text { Radiation Ratio } \\
\text { (Growing Season) }\end{array}$ \\
\hline $\begin{array}{c}59^{\circ} \mathrm{N}, 103 \\
{ }^{\circ} \mathrm{E}, 250-400 \\
\mathrm{~m}\end{array}$ & varied & hilly & 100 & $900 \times 900,81$ & podsols & 41.0 & 20.5 & $-23.4 \pm 16.5$ & $12.5-71.3$ & 115 & 176 & $0.47 / 0.53$ \\
\hline $\begin{array}{l}52^{\circ} \mathrm{N}, 91^{\circ} \mathrm{E}, \\
100-3000 \mathrm{~m}\end{array}$ & north/south & $\begin{array}{l}\text { sloped, } \\
\text { ridge }\end{array}$ & 100 & $\begin{array}{c}12 \times 581 \\
69.72\end{array}$ & $\begin{array}{c}\text { cambisols, } \\
\text { kastanozems }\end{array}$ & 26.5 & 13.25 & $-30.1 \pm 19.9$ & $3-47$ & 285 & 303 & $0.5 / 0.5$ \\
\hline
\end{tabular}


To understand how the fire regime may change in the near future within the middle taiga ecotone, we simulated an 81-ha real terrain landscape with edaphic and climate characteristics from the Severnyi Leshoz $\left(59^{\circ} \mathrm{N}, 103^{\circ} \mathrm{E}\right.$ ) within the Chuno-Angarsky sub-ecoregion. To represent the landscape, a 81-ha square area was randomly selected from the ASTER DEM [66] from within the $58-59^{\circ} \mathrm{N}, 102-103^{\circ}$ E granule and resampled at $10 \mathrm{~m} \times 10 \mathrm{~m}$ to match the plot size in the simulation. Monthly average temperatures and precipitation sums were computed from 6- and 3-h measurements obtained at the Ust'-Ilimsk World Meteorological Organization (WMO) station (\#30117, 58 ${ }^{\circ} 12^{\prime} \mathrm{N}, 102^{\circ} 45^{\prime} \mathrm{E}, 217 \mathrm{~m}$ above mean sea level (a.m.s.l.)) for the 1960-1990 timeframe [63,64] and adjusted for elevation at the plot-level based on a $6.5^{\circ} \mathrm{C} / \mathrm{km}$ environmental lapse rate [67]. Historical (1960-1990) climatology for the WMO station is shown in the a. The simulation was started from bare ground and run for 300-years on site index III soils, which dominate in the region [68]. The 300-year duration is comparable to durations for which fire regime was determined based on dendrochronology in this region: 270 years [12] and 300 years [5]. The start year of the simulation corresponds to the year 1800 . This allowed the forest to grow to contain stands 110-200 years old by the year 1990. The condition of these forests is described by Kukavskaya et al. [29] around 1990, which has been identified as the start of the intense warming period [22]. An MFRI of 52.9 years was used for this area, with $7 \times$ amplification for severe fire years [49] that correspond to drought, i.e., 2003 compared to the 8-year average for 2001-2007 [5]. This MFRI is the most recent and is comparable to what has previously been reported for this region: 56.8 years [26] and 47 years [12]. Stand aggregate structure (stand height, biovolume) and composition (percent contribution of each species based on basal area) generated under historical climate conditions were qualitatively compared to literature values for this leshoz as presented by Gustafson et al. [17] and forest characteristics reported for the broader central Siberian region near the middle- and southern-taiga boundary $[5,67,69]$. The percent of area burned annually was compared to the literature values for the region and for Russian forests in general $[5,20,70,71]$. The fraction of fires of different intensities was compared to ground-, aerial- and space-based observations [12,72]. Then, the drought-trigger for forest fire was activated, the simulations were re-run, and model output again qualitatively compared against observed vegetation and fire regime characteristics.

To understand changing fire dynamics in the mountainous southern taiga, an ecotone where nearly half of the fires in Russia occur [55], we simulated an idealized mountain with south- and north-facing slopes, located at $52^{\circ} \mathrm{N}, 91^{\circ} \mathrm{E}, 100-3000 \mathrm{~m}$ a.m.s.l. Monthly temperature values were obtained from the Kyzyl WMO station (\#36096, 51 $24^{\prime} \mathrm{N}, 94^{\circ} 14^{\prime} \mathrm{E}, 629 \mathrm{~m}$ a.m.s.l.) and adjusted for elevation at the plot-level using the environmental lapse rate of $6.5^{\circ} \mathrm{C} / \mathrm{km}$ [67]. Historical (1960-1990) climatology for the WMO station is shown in the b. Different types of soils are encountered along the slopes, and the site index was specified, such as to obtain the greatest productivity mid-slope (site index I) and least near the ridge top where soils are shallow (site index V) following the description from the literature [73-75] and soil data from a georeferenced database [61]. The simulated forest structure and composition, stored carbon (biomass) and the pattern of forest distribution generated without accounting for disturbance (no fire) under historical and possible future climatological conditions along this mountain have previously been qualitatively and quantitatively compared to field observations and modeling studies described in the literature [45]. Here, we qualitatively compare the annual area burned, fire intensity (fire type), as well as the locations of more frequent burns on the landscape to the descriptions in the literature $[12,14,29,32]$. We evaluated whether forest characteristics and distribution are better approximated when disturbances (fire) are included in the simulation and estimated how fire disturbances may affect the landscape pattern and the ability of the ecosystem to store carbon under a warmer climate in the near future using the observed warming and precipitation $[22,65,76]$ trends for the region and extrapolating them forward linearly to the year 2100.

For each location, we used the following fire module modes in 300-year simulations:

(1) historical (1960-1990) temperature and precipitation (climate), no fire;

(2) historical (1960-1990) temperature and precipitation (climate), probabilistic fire;

(3) historical (1960-1990) temperature and precipitation (climate), drought-triggered fire; 
(4) recent warming and precipitation changes (1990-2014) extrapolated to 2100, no fire;

(5) recent warming and precipitation changes (1990-2014) extrapolated to 2100, probabilistic fire; recent warming and precipitation changes (1990-2014) extrapolated to 2100, drought-triggered fire.

\section{Results and Discussion}

Validation of the new fire subroutine is difficult, because data that reflect annual wildfire extent, frequency and intensity for the different regions across Siberia do not agree between sources [24,60]. Aviolesokhrana reports significantly lower values for burned areas than analysis of remote sensing data [6] for the same time frame, both of which differ from estimates for an average fire year based on an MFRI [3]. Remote sensing is not able to capture small fires ( $<1000 \mathrm{ha})$ and often does not capture low-intensity ground fires [6,77]. De Groot et al. [5] estimate that approximately one third of all fires were not captured in satellite-based imagery during their study period of 2001-2007. For this reason, a qualitative analysis was deemed more appropriate for fire module validation.

\subsection{Middle Taiga: No Fire}

Simulation of middle taiga forest without fire disturbances results in a larch (Larix sibirica)-dominated forest, with approximately $30 \%$ contribution from pine (Pinus sylvestris) and cedar (Pinus sibirica), but all other species suppressed. This forest exhibits an average biovolume of $200-300 \mathrm{~m}^{3} \cdot \mathrm{ha}^{-1}$, stand aggregate basal area of $>60 \mathrm{~m}^{2} \cdot \mathrm{ha}^{-1}$ and a leaf area index of $6-14 \mathrm{~m}^{2} \cdot \mathrm{m}^{-2}$. Although realistic, these simulated stands do not compare well to ground-based observations of forest structure and species composition from the Angara river basin in Irkutsk and Krasnoyarsk regions. This may be due to incongruency in stand age (time from bare ground or catastrophic disturbance, e.g., intense crown fire) between the simulated and actual forests.

\subsection{Probabilistic Fire}

When the probabilistic fire is activated, the model appropriately simulates stand composition, with pine and larch co-dominating the landscape and only a few dark conifers and hardwoods. Conifers comprise $90 \%$ of vegetation. Simulated 110-200-year-old forest was compared to the average conditions along the Angara River described by Kukavskaya et al. [29]. The simulated basal area $\left(32.5 \pm 0.5 \mathrm{~m}^{2} \cdot \mathrm{ha}^{-1}\right)$ is in line with the observed basal area for this region (30-50 $\mathrm{m}^{2} \cdot \mathrm{ha}^{-1}$ [29]). The 110-200-year-old simulated forests (from bare ground) contain pine stands with $195 \pm 19 \mathrm{~m}^{3} \cdot \mathrm{ha}^{-1}$ biovolume, larch stands with $112 \pm 11 \mathrm{~m}^{3} \cdot \mathrm{ha}^{-1}$ biovolume and spruce and fir mostly in the understory and representing $28 \pm 1 \mathrm{~m}^{3} \cdot \mathrm{ha}^{-1}$ and $9 \pm 1 \mathrm{~m}^{3} \cdot \mathrm{ha}^{-1}$, respectively. This compares well with the reported forest structure from Severny leshoz, wherein over $50 \%$ of pines are in the mature and over-mature stage and have an average biovolume of $210 \mathrm{~m}^{3} \cdot \mathrm{ha}^{-1}$; larch stands were at an average age of 113 years at the time of observation with a biovolume of $138 \mathrm{~m}^{3} \cdot \mathrm{ha}^{-1}$ [68]. Spruce and fir stands contribute less to overall forest composition and are concentrated along river banks and on the upper slopes, respectively. Spruce and fir are mostly in the understory in the simulation and fairly equally dispersed across the simulated landscape, which represents 81-ha of the more upland territory.

In Severnyi leshoz, pine comprises approximately $50 \%$ of the stands, larch $29.3 \%$, spruce $5.2 \%$, fir $2.6 \%$, and there are birches and aspen regenerating in burned or clearcut areas $(<20 \%)[68]$. Correspondingly, simulated stands are comprised predominantly of pine and larch (Table 5). The simulated stand average biovolume of dark conifers and hardwoods is smaller than observed. The former is likely due to not capturing the niches occupied by firs and spruce in the selected DEM section for the simulation. The latter, however, is likely due to two reasons: (1) not accounting for the timber harvest and management that has occurred on leshoz territory since 1958; and (2) the nature of the probabilistic fire subroutine. 
Table 5. The values are $\mu(\sigma)$ percent composition or a range. Values from the simulation are based on species contribution to total stand basal area.

\begin{tabular}{|c|c|c|c|c|c|c|c|c|}
\hline Source & Region & ABSI & Betula spp. & LASI & PIOB & PISI & PISY & Populus spp. \\
\hline de Groot et al., 2013 [5] & Chuno-Angara ecoregion & 4.14 & 8.74 & 36.2 & 5.52 & 15.9 & 27.1 & 2.5 \\
\hline Gustafson et al., 2010 [17] & Severnyi leshoz & $5-10$ & $4-10$ & $15-35$ & $6-25$ & $7-14$ & $20-40$ & $4-15$ \\
\hline Irkutsk Region Forest Report [68] & Severnyi leshoz & 2.6 & 14 & 29.3 & 5.2 & 11 & 33.4 & 4.5 \\
\hline Irkutsk Region Forest Report [68] & Irkutsk regional average & 3.6 & 9.0 & 28.8 & 5.2 & 18.3 & 29.6 & 4.1 \\
\hline SIBBORK no fire & $59^{\circ} \mathrm{N}, 103^{\circ} \mathrm{E}$ & $1.1(0.4)$ & $0.4(0.04)$ & $52.8(0.8)$ & $2.4(0.8)$ & $15.5(2.7)$ & $27.7(2.8)$ & $0.2(0.04)$ \\
\hline SIBBORK drought fire & $59^{\circ} \mathrm{N}, 103^{\circ} \mathrm{E}$ & $5.3(0.6)$ & $0.3(0.02)$ & $27(3.3)$ & $11.4(0.3)$ & $17.5(1)$ & $38.1(3.1)$ & $0.4(0.05)$ \\
\hline de Groot et al., 2013 [5] & Southern-Altai/Tuva & 0.1 & 3.1 & 61.1 & 0.7 & 32.8 & 1.9 & 0.3 \\
\hline SIBBORK no fire & Southern taiga & $10.5(0.3)$ & $0.5(0.1)$ & $21.4(1.2)$ & $33.3(5.3)$ & $29.1(4.4)$ & $5.1(0.5)$ & $0.3(0.01)$ \\
\hline SIBBORK drought fire & Southern taiga & $12.3(0.2)$ & $0.5(0.09)$ & $23.3(1.1)$ & $30(3.6)$ & $26.8(3.2)$ & $6.7(0.5)$ & $0.4(0.01)$ \\
\hline
\end{tabular}


The region of central Siberia along the Angara River is one of the most heavily disturbed areas by timber harvest. Hardwoods (birch and aspen) regenerate in the clearcuts, which are not represented in the simulation because SIBBORK does not have a timber harvest subroutine at this time. Additionally, the burning of the plots in this probabilistic fire subroutine is not synchronized, so some plots in the 81-ha simulation burn each year, creating small $10 \mathrm{~m} \times 10 \mathrm{~m}$ gaps in the canopy. This only slightly suppresses the stand aggregate biovolume, and the shift of composition toward a higher contribution from birch and aspen is not observed. The $10 \mathrm{~m} \times 10 \mathrm{~m}$ gaps are likely not large enough to promote regeneration of these shade-intolerant species. However, the presence of small gaps in the canopy likely promotes regeneration by growth of branches of trees already dominant in the area, or the promotion of trees from the subcanopy into the main canopy, rather than sprouting and promotion of young saplings into the sub or main canopies. This may explain the higher contribution from subcanopy species (fir, spruce) in the simulation, compared to observations. Otherwise, the simulated species composition compares well to stand characteristics reported by Gustafson and colleagues [17] (Table 5).

The annual area burned using the probabilistic fire mode under a historical climate $(1.87 \% \pm 0.47 \%$, range: $0 \%-3.4 \%)$ compares well to some of the estimates suggested in the literature for central Siberian mixed forests (1.89\%, range: $0.4 \%-4.7 \%$ [5]) and for western and eastern Siberia in general (1.76\%, Wirth, 2005; see Table 3 for others). The simulated area burned is somewhat larger than suggested by Furyaev [12,56], who estimate that with a $50 \pm 20$ year MFRI $0.6 \%$ of total Russian forest area burns annually. However, estimates of annual area burned, whether across all of Russian boreal forests or within central Siberia, vary widely across literature and official government reports from the USSR [60]. Figure 2 shows the wide array of estimates across several decades. Using the largest and smallest forest area burned estimates and the official estimate of total forest cover of 797 Mha in Russia [78], $0.025 \%$ to $4.8 \%$ of forest burn annually. This is comparable to the estimate for central Siberia of $0.4 \%-4.7 \%$ /year [5] and is captured by the simulated range. Scots pine forests in central Siberia and near the Angara river burn more frequently [12], but the reported area burned may be significantly underestimated, because the fire regime across Russian boreal forests is dominated by ground fires, which are notoriously difficult to detect in satellite-based observations $[5,60,79]$ and may not be adequately represented in the data presented in Figure 2. Although the crown-to-ground fire ratio varies from year to year in the simulation, over the long-term (>decade) approximately $20 \%$ are crown fires, which result in complete mortality on the plot, and $80 \%$ are ground fires, which selectively remove species from the plot, significantly changing the light environment on the affected and nearby plots. In some years, no crown fires are observed within the 81-ha simulated area, and over the course of the 300-year simulation, a few years have no fires at all. The simulated crown-to-ground fire ratio is in alignment with observed and estimated crown fire fraction: 16\%-24\% [32], 22\% [14], 20\% [3,4,31], $33.6 \%$ [77], $25 \%$ crown [2,80], $6.5 \%$ crown [5] and a similarly low estimate of $7 \%$ crown with $22 \%$ intense ground (may consume much vegetation and exhibit similar intensity as crown fires) [72]. In larch- and pine-dominated forests, crown fires can comprise as much as $42 \%$ of total fires [77]. 


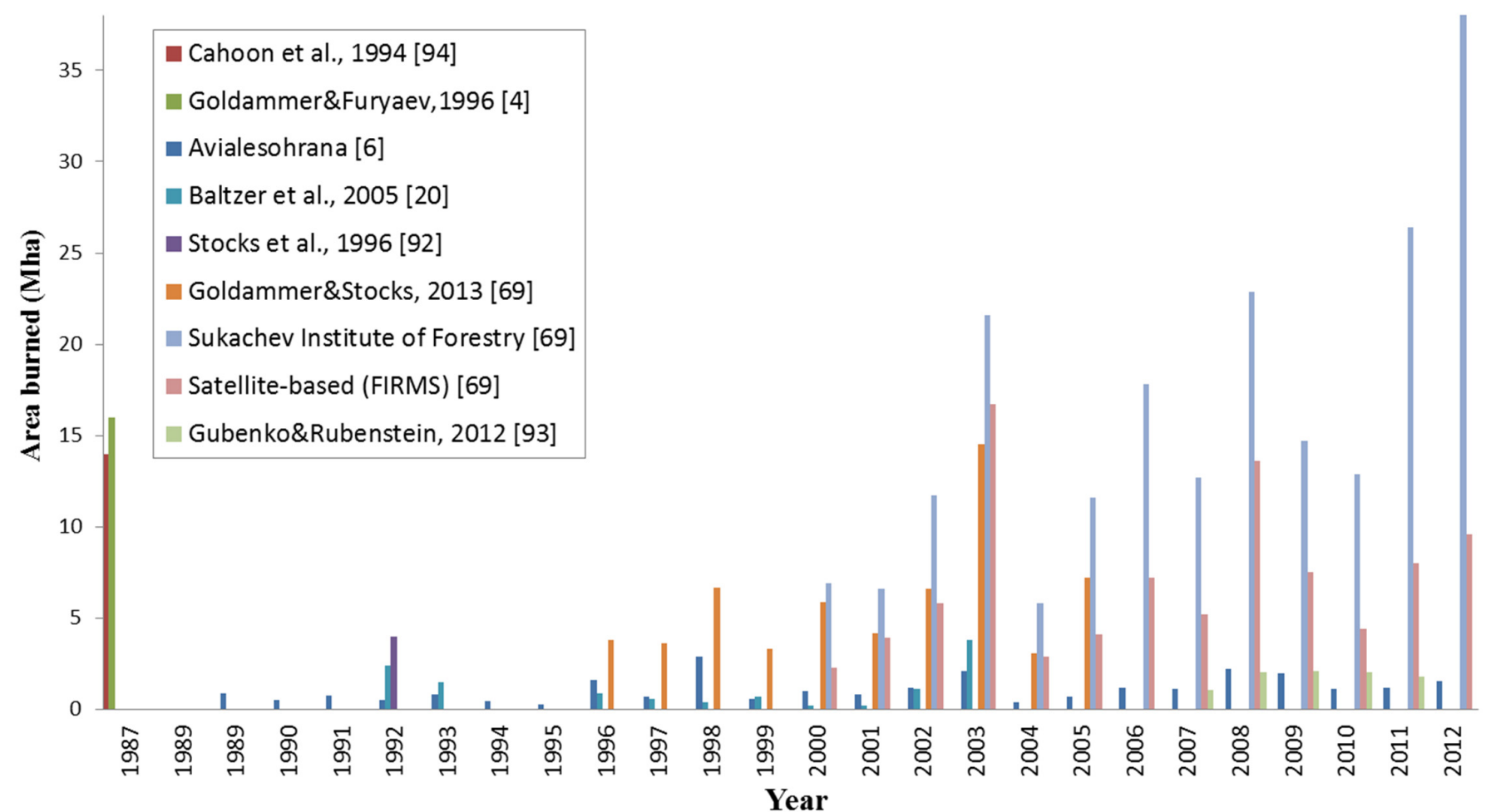

Figure 2. Forest area burned each year varies widely. Furthermore, there are great discrepancies in estimates of burned forest area conducted by different techniques (ground, aerial, satellite-based, MFRI-based). The Conard and Ivanova [3] estimate based on MFRI that annual area burned is 12 Mha (dashed line); Groisman et al. [81] suggest that 10 Mha (dotted line) of Russian forests burn annually; and Isaev et al. (2002) estimate an area in the range of 2-5.5 Mha (shaded band). Goldammer et al. [71] suggest that up to $3.4 \%$ of Russian forests ( $>30$ Mha) can burn in a single year. 


\subsection{Drought-Triggered Fire}

Using the drought-triggered fire mode and historical climate conditions, the simulated fire regime is very similar to the probabilistic MFRI-based fire, because this region has not been experiencing significant drought conditions during the 20th century, except in pine stands on sandy soils (Figure 3). Historically, droughts were experienced 1-3-times per decade during the 19th and 20th centuries in this region [15]. Over the course of the 190 years of simulation under a historical climate, only $2-3$ severe drought events occur with $>70 \%$ of the growing season at or below wilting point that trigger more fires than in the probabilistic fire mode. Although warming has been observed in central Siberia over the last several decades, no appreciable changes in precipitation have been noted (Table 6; [22]). However, if precipitation is decreased by as little as $5 \%$ while maintaining the historical temperature conditions, drought does occur, and the simulated fire regime changes, along with forest structure and composition. This middle taiga ecosystem is likely to be affected by increases in temperature, because the increase in PET demands is likely to outpace any marginal increases in precipitation. In the simulation, drought events, with as much as $70 \%$ of the growing season at or below wilting point, begin to occur in 2060. Furthermore, when the drought-triggered fire mode is activated under a warming scenario, the annual area burned and the crown:ground fraction increase to $2.69 \% \pm 1.87 \%$ (range $0.40 \%-7.89 \%$ ) and $32.8 \%$, respectively, by late 21st century (time average of years 2050-2100). This shifts forest composition toward greater contribution of hardwoods (Betula spp., Populus spp.), especially in areas where gaps are formed the size of multiple plots. Simulated post-fire regeneration is predominantly comprised of pine and hardwood saplings which compares well with observations from central Siberia [58].

Table 6. Observed warming $\left({ }^{\circ} \mathrm{C} /\right.$ year) and precipitation $(\mathrm{mm} /$ year) trends by location and season during 1990-2014. Concurrently with small increases in precipitation in southern taiga, snow water content has been decreasing at the rate of $0.82 \mathrm{~mm} /$ year in recent years, compared to the 1971-2000 average [22].

\begin{tabular}{llllll}
\hline Site & Climate Variable & Winter & Spring & Summer & Autumn \\
\hline \multirow{2}{*}{ Middle taiga } & Temperature $\left({ }^{\circ} \mathrm{C} / \mathrm{y}\right)$ & +0.01 & +0.073 & +0.042 & +0.037 \\
& Precipitation $(\mathrm{mm} / \mathrm{y})$ & -0.04 & +0.47 & +0.45 & +0.36 \\
\hline \multirow{2}{*}{ Southern taiga } & Temperature $\left({ }^{\circ} \mathrm{C} / \mathrm{y}\right)$ & 0 & +0.055 & +0.045 & +0.028 \\
& Precipitation $(\mathrm{mm} / \mathrm{y})$ & +0.44 & +0.47 & +0.12 & +0.32 \\
\hline
\end{tabular}

Using the probabilistic fire regime, the burn areas are randomly distributed and only small gaps are formed in the canopy. This facilitates the growth of canopy dominant larch and pine to close up the small gaps, and suppresses the dark conifers (fir, spruce) in the understory. This is shown by an increase in DBH of the former and a decrease in the latter over the course of 1-3 decades following a fire event on a plot. In the central Siberian Angara region, few droughts occur under a historical climate. Historical droughts affect multiple plots, and in the drought-triggered mode, larger fires are generated in the simulation during those years. Regeneration of hardwoods occurs following drought-triggered fires, but is negligible in the probabilistic fire mode, where only small, $10 \mathrm{~m} \times 10 \mathrm{~m}$ gaps are generated in the forest.

Under a warming scenario not accompanied by changes in precipitation (Figure A1c), droughts become more frequent and severe (affecting more plots) after the year 2050. Prior to the onset of more frequent droughts, hardwoods regenerate in gaps, whereas after 2050 pulses of fir and spruce saplings regenerate and release occur following drought-triggered fire in the simulation. The average (Lorey's) height of canopy dominant larch and pine decreases between the years 2050 and 2100. The average DBH and leaf area of cedar (Pinus sibirica) spruce, fir, and larch decrease significantly during the second part of the 21st century, and dark conifers almost disappear from the simulation by the year 2070. These simulated structural and compositional changes are similar to the observed suppression 
of canopy-dominant pine that facilitates a release of subcanopy and understory spruce and fir trees following an increase in area burned in recent decades [6,82]. When severe droughts begin to occur more frequently (2-3-times per decade), all species become suppressed. The stand basal area decreases by $20 \%$ between 2050 and 2070 . The change in forest structure (more gaps, leading to more light within and below the canopy) and decrease in competition releases pine (accelerated rate of DBH increase), as well as promotes new growth and its foliage to fill in the gaps (increase in stem density and leaf area). However, these pines experience stunted growth, with stand biovolume decreasing by almost $50 \%$ by the year 2100 . The disappearance of dark conifers following intensification of the fire regime has been suggested by Furyaev [12] and others (Gorbachev and Popova, 1996; Sannikov and Goldammer, 1996) $[48,49]$. Furthermore, field observations show that under drier (soil) conditions and following an increase in fire activity (frequency and intensity), forested ecosystems do not regenerate. Even in central Siberia, some areas that are repeatedly burned are unable to regenerate as forest, and transition to grassland/meadow or steppe $[28,59]$.

a)

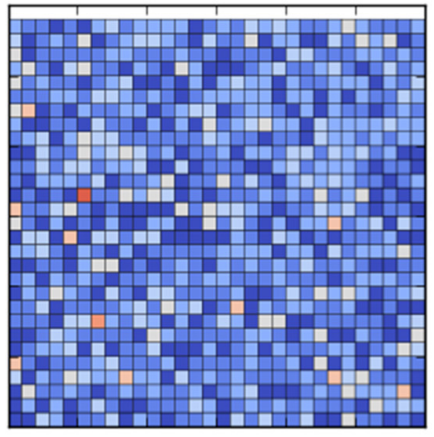

b)

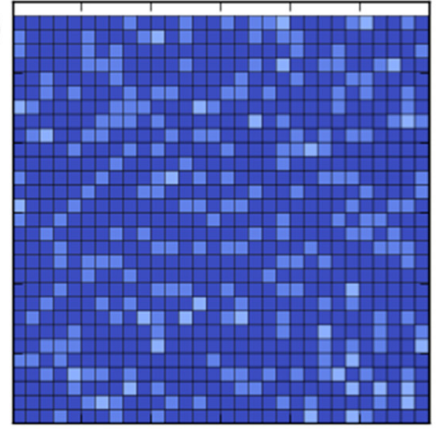

c)

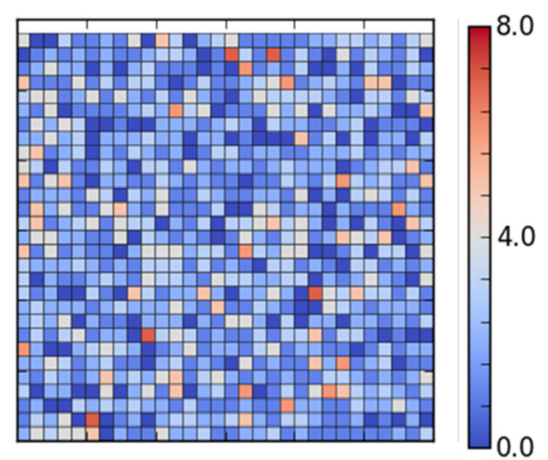

d)

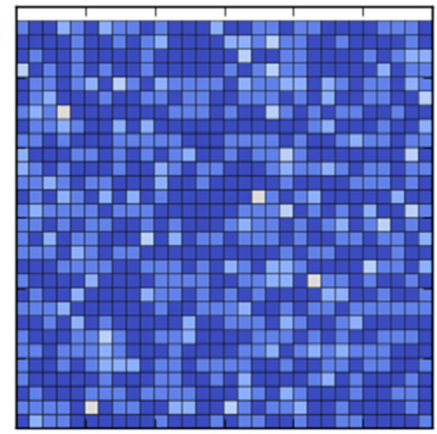

Figure 3. Distribution and frequency of fire across a flat-terrain 9-ha simulation with climate and edaphic conditions from central Siberia: (a) probabilistic MFRI-based fire regime with historical climate; (b) crown fires from (a); (c) drought-triggered MFRI-based fire regime with historical climate; (d) crown fires from (c). Note that there is no distinct spatial pattern to fire distribution when the ecosystem is not subject to drought and when there are no patterns in topographic, edaphic, or environmental conditions across the landscape (i.e., when the landscape and environmental conditions are homogeneous). The color bar represents the number of times a plot has burned over the course of 80 years. MFRI $=52.9$ years.

\subsection{Southern Taiga: No Fire}

The spatially-explicit simulation is able to resolve the expositional distribution of vegetation in mountainous southern taiga, with forest dominated by dark conifers on the north-facing slopes, a ribbon of larch-dominated forest mid-slope on the south-facing slope, no arboreal vegetation above $1800 \mathrm{~m}$ and $2200 \mathrm{~m}$ on the north- and south-facing slopes, respectively (corresponds to alpine tundra), and no trees below $1400 \mathrm{~m}$ on the south-facing slope (corresponds to steppe). This vegetation 
distribution matches field-based observations from southern Altaj and Tuva regions under a historical climate [47]. Furthermore, larch forests are replaced by larch forests in the simulation following fire, as is observed in this region [58]. When the observed warming trend is applied throughout the 21 st century in simulations without disturbance, arboreal vegetation on both slopes shifts upslope. The lower timberline on the south-slope also shifts upslope, and by the year 2100 the expositional ribbon forests disappear almost entirely from mountains less than $3000 \mathrm{~m}$ tall. When the fire regime is activated, the stand aggregate biovolume on the landscape decreases, and the disappearance of the expositional forest on the south-facing slope occurs earlier, mid-century.

\subsection{Probabilistic Fire}

Using only the MFRI (probabilistic fire mode) and historical climate, the annual area burned in the simulation $(0.22 \% \pm 0.06 \%$, range: $0 \%-0.4 \%)$ compares well to the values presented in the literature for southern taiga $(0.25 \%$ [56]). In the probabilistic fire mode, the 20:80 crown:ground fire ratio is maintained. However, in severe fire years, the observed ratio approaches 50:50. Wildfire occurrence and the crown:ground fire intensity ratio does not change with changing environmental conditions in the probabilistic fire mode.

\subsection{Drought-Triggered Fire}

When the drought-trigger is activated, average annual area burned under a historical climate increases to $0.30 \% \pm 0.12 \%$ (range: $0 \%-0.77 \%$ ), with $31 \%$ of those as crown fires. This range still encompasses the observed multidecadal average $(0.25 \%$ [56]). However, reports of area burned vary widely for this region [83], and in severe fire years (e.g., 2002) it is estimated that as much as $9 \%$ of this region burns (steppe and forest included) [84]. This value cannot be compared directly to simulated area burned, because the simulation only includes forested area, except that we expect the simulated area burned in severe fire years to be significantly less than $9 \%$, because the predominant vegetation that burns in this region is the steppe, which is not included in the simulation. An increase in crown fire proportion is appropriate in drought conditions, because the vegetation is drier and facilitates ignition and higher severity burning. The slight increase in annual area burned in this mode is representative of the specific forested region near the southern boreal zone boundary, rather than the average conditions in this region, much of which is covered by steppe.

In order to reproduce the significantly larger crown:ground fire ratio during severe fire years, the average fraction of crown fires is increased to $35 \%$. This fraction was determined iteratively and results in $20 \%-53 \%$ crown fires during severe fire years, and thus in the simulation, as in observations, the crown:ground fire ratio can be as high as 50\% during severe fire years. It is possible that the crown ratio is overestimated, because "drought" is defined as a year during which at least one tree on a plot is stressed from lack of soil moisture. Based on this definition, under a historical climate, drought occurs in most years in the simulation of the southern taiga, but only during a few years in the simulation of middle taiga.

Interestingly, SIBBORK appropriately reproduces the distribution of vegetation (species and biovolume) along both the north- and the south-facing slopes (Figure 4) [47]. The model appropriately represents drought, and simulates differential changes in soil moisture with increase in temperatures not accompanied by appreciable changes in precipitation. Furthermore, drought-triggered fires ignite in areas of drought on the landscape and in the appropriate forest types: larch- and pine-dominated stands, but not usually in more humid dark conifer forests. The occurrence of higher-intensity crown and high-intensity ground fires is also appropriately larger in pine and larch stands [83] and on south-facing slopes. The return of fires is more frequent to the south-facing slopes. The synchronization of the environmental conditions and the fire regime is not explicitly coded and is an emergent property of the SIBBORK model coupled to the DISTURB-F subroutine in drought-triggered mode. 
a)

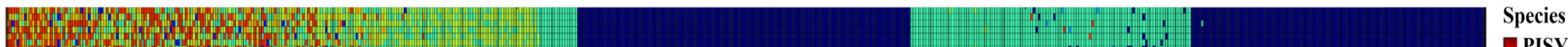

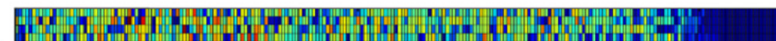

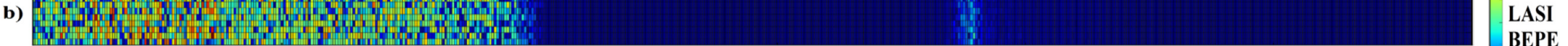

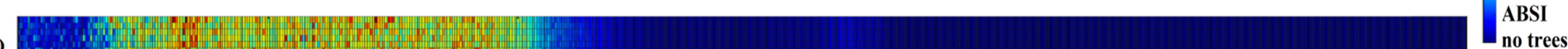

c)

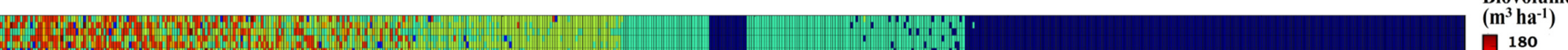

d)

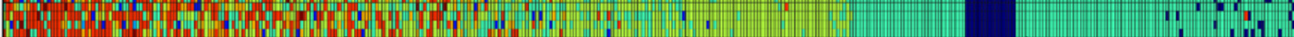

e)

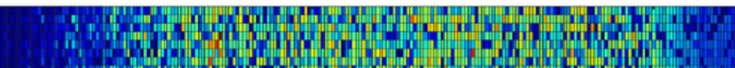

$200 \mathrm{~m}$

$1000 \mathrm{~m}$

$2000 \mathrm{~m}$

3000m

$2000 \mathrm{~m}$

RIDGE

$1000 \mathrm{~m}$

SOUTH-FACING SLOPE

$200 \mathrm{~m}$

180
160

140

120

NORTH-FACING SLOPE

Figure 4. Simulated species and biovolume distribution along an idealized mountain with climate and edaphic conditions from southern Siberia: (a) species distribution under the historical (1960-1990) climate, no disturbance; (b) biovolume distribution under the historical climate, no disturbance; (c) species distribution from the year 2100 under a warming scenario, no disturbance; (d) species distribution from the year 2100 under a warming scenario, drought-triggered fire; (e) biovolume distribution from the year 2100 under a warming scenario, drought-triggered fire. Larch is represented by teal color, and although many plots appear to have larch along the south slope, the wood biovolume of these sparse saplings is quite small and they do not sequester or store much carbon. Each grid cell represents one $10 \mathrm{~m} \times 10 \mathrm{~m}$ plot. The top color bar represents species type in $(\mathrm{a}, \mathrm{c}, \mathrm{d})$. The lower color bar represents biovolume in $(\mathrm{b}, \mathrm{e})$ in $^{3} \cdot \mathrm{ha}^{-1}$. 
Application of the drought-triggered fire regime to simulation of potential future climate based on linear extrapolation of observed warming (Figure A1d) in the region along the southern boundary of the boreal zone results in greater incidence of drought, both on the south-facing slope and at lower elevations along north-facing slopes. Under this warming scenario, vegetation shifts upslope on both aspects, and the ribbon forests on the south-facing slopes decrease in vigor and biovolume, which is in accordance with observations $[38,39,85]$ and previous modeling studies $[47,86]$. Warming ambient temperatures increase the PET demands on vegetation, but if no concurrent increase in precipitation occurs, vegetation becomes stressed and either dies from temperature-based drought stress or more easily succumbs to mortality from insects, fire, pathogens, or windthrow. In a warmer climate, both the annual area burned and fire intensity increase in southern taiga. Using the model, the annual area burned in 2100 is forecast to be $0.36 \% \pm 0.16 \%$ (range: $0.2 \%-0.9 \%$ ), with $35 \%$ as crown fires averaged across the mountain. This corresponds to $45 \%$ of forest fires occurring on the south-facing slope and $55 \%$ on the north-facing slopes, with $42 \%$ of the fires on the south-facing slopes as crown fires compared to $23 \%$ on the north-facing slope. Note that fire is only simulated on plots with trees, and fewer plots on the south-facing slope are populated by arboreal vegetation. Most of the plots on the south-facing slope do not have trees and correspond to steppe at lower elevations (below 1400-1500 m a.m.s.l.) and alpine tundra at higher elevations (above 2100-2200 $\mathrm{m}$ a.m.s.l.). Therefore, although only $45 \%$ of the simulated fires occur on the south-facing slope, the density of fire occurrence within the ribbon of forest on the south-facing slope is greater than on the north-facing slope.

Increases in annual area burned have been forecast and observed during recent severe fire years [18,71]. Figure 5 shows the changes in distribution of fire along the idealized mountain from the historical climate fire regime to what the fire regime may resemble in 2100 if the warming trends observed during the last 25 years continue without appreciable changes in precipitation. Spatial patterns begin to appear in the fire distribution when the drought trigger is activated, with the forests on south-facing slopes more heavily damaged by fire. Crown fires tend to cluster on the south-facing slopes and lower north-facing slopes. Although Groisman et al. [21] point out that no appreciable changes in precipitation have been observed in southern taiga over the last 50 years, Tchebakova and Parfenova [65] argue that $4 \%-8 \%$ less precipitation is currently received in the boreal forests along the southern boreal boundary (Sayan-Altaj mountain complex and Tuva Republic) compared to the historical average. Decrease in precipitation will further drought-stress the vegetation, likely increasing the frequency of fire and the crown-to-ground fire ratio, and potentially facilitating a biome shift from forest to steppe on the south-facing slopes mid-21st century.

Recent field-based observations have found that the forests in southern Siberia are losing their ability to regenerate post fire and other landscape disturbances under a warming climate [29,59,87]. The changes in the climate and disturbance regimes are not just shifting the southern taiga ecotone northward into what was historically middle taiga [56], but the forest-covered area, both in middle and southern taiga, is decreasing [59]. Suppressed forest regeneration was also apparent in our simulation studies.

Post-fire vegetation dynamics depend on fire size and intensity. Stand structure and, therefore, light geometry, differ significantly following a ground fire versus a stand-replacing crown fire, both in the field and in the simulation. Resistor trees (see Table 1) survive the low-intensity ground fires, and the regeneration that follows facilitates the establishment of shade-tolerant coniferous saplings. After a stand-replacing, high-intensity crown fire, however, sufficient light environment facilitates sprouting of shade-intolerant broadleaf or deciduous conifer (larch) species, which matches observations from the boreal forest $[8,88]$. High-intensity crown fires are often followed by regeneration of even-aged cohorts of shade-intolerant species (birch, aspen, larch), whereas low-intensity ground fires allow regeneration of cohorts of shade-tolerant (dark conifers) and somewhat-shade-tolerant species (pine) in the understory [17]. Stand productivities along these two trajectories are vastly different, with shade-tolerant conifers exhibiting lower productivity. 

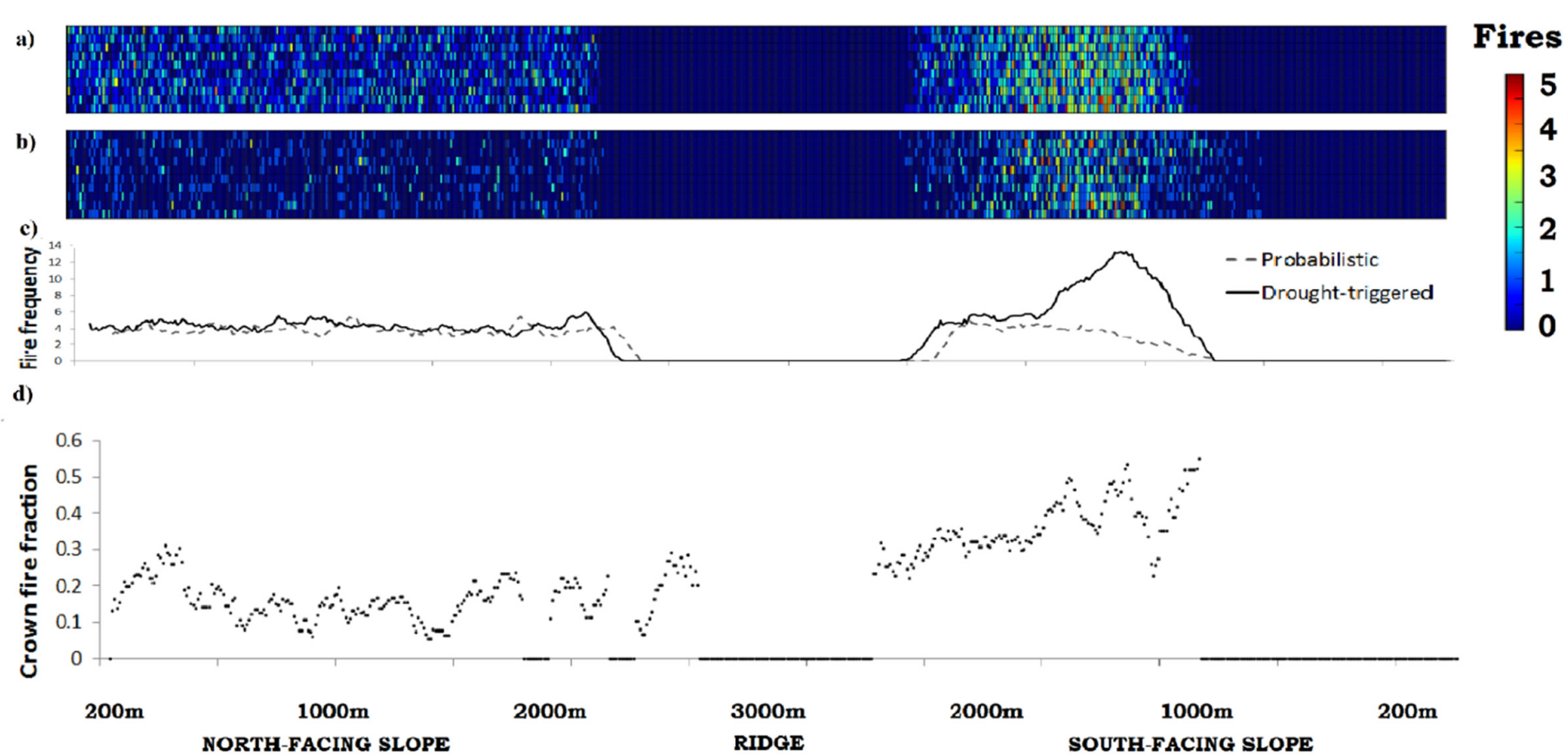

Figure 5. Location and frequency of fire along an idealized mountain with climate and edaphic conditions from southern Siberia: (a) probabilistic MFRI-based fire regime with historical climate; (b) drought-triggered fire regime with historical climate; (c) comparison of fire frequencies along an elevational gradient on north- and south-facing slopes (frequency in plot-sized fires per hectare per century); (d) crown fire fraction along an elevational gradient on north- and south-facing slopes under a warming scenario. The fire is randomly distributed across the forested landscape under a probabilistic fire regime, but with a drought-trigger spatial patterns appear in the locations and frequency of fire across the landscape, and most of the crown fires are concentrated on the south-facing slope, with maximum crown:ground fraction approaching $50 \%$. The color bar for $(\mathrm{a}, \mathrm{b})$ represents the number of- a plot has burned over the course of a 100-year simulation. Each grid cell represents one $10 \mathrm{~m} \times 10 \mathrm{~m}$ plot. 
Overall, the model appears to simulate fire in the appropriate locations on the landscape, and synchronicity is observed between environmental conditions and the fire regime. There is coupling between increased drought and increased occurrence of fire, as well as increased proportion of crown fires in the simulation alongside warming of ambient temperatures without appreciable changes in precipitation. We did not modify the MFRI or the crown-to-ground fire fraction for the future climate over the course of each simulation. Instead, we let the changes in the environmental conditions (temperature, precipitation, PET, soil moisture, growing season duration, fraction of growing season in drought) to affect the probability of ignition through the drought-trigger, allowing any changes in the fire regime to arise as emergent properties of the simulation. The growing season is determined based on simulated temperatures and, therefore, increases in duration under a warming scenario. Correspondingly, any drought that occurs within the new, longer growing season, can serve as a drought trigger for fire events, consequently lengthening the fire season, as has been observed in central and southern Siberia $[28,59]$. As most of the precipitation is received during the summer months, increased drought and, therefore, fire, are observed during the spring and fall months within the growing season, which aligns with observed changes in the fire regime in southern and middle taiga $[5,28,56,58]$. Although tree mortality in SIBBORK is assessed at an annual time step, drought conditions are computed for each month, capturing an increase in spring and autumn drought conditions. This is another example of emergent behavior of the coupled SIBBORK-DISTURB-F model.

Modeling facilitates the study of forest-fire dynamics and interpolates where the satellite record does not provide coverage due to cloud cover, smoke, insufficient resolution, or lack of fire activity during satellite overpass, which can account for as much as a third of satellite imagery over Eurasian boreal forests [5]. Most importantly, however, we have no observations of the future, and the simulation of changes in forested ecosystems due to shifts in climate and fire regimes can facilitate insight into climate-fire-vegetation feedbacks and how the landscape-scale balance of carbon may change in the near future. Modeling results can be used to prioritize allocation of efforts toward conservation, mitigation, and forest management. For example, the effect of fires on the carbon balance can be estimated by using the simulated accumulated above- and below-ground biomass to estimate the amount of carbon sequestered from the atmosphere, and published estimates for emissions from fires $[6,26,89]$. Conard and her colleagues [6] estimated that $22.5 \mathrm{tC}$ are emitted for each hectare burned in Eurasia via a high-intensity crown fire, $8.6 \mathrm{tC} \cdot \mathrm{ha}^{-1}$ emitted in moderate-intensity ground fires, and $2.3 \mathrm{tC} \cdot \mathrm{ha}^{-1}$ are emitted in low-intensity surface fires. These emission estimates can be used to convert area annually burned in the simulation to the amount of carbon released to the atmosphere during the associated simulation year. Using the historical climate coupled with drought-triggered fire mode, the amount of carbon released into the atmosphere would be approximately $12 \mathrm{tC} \cdot \mathrm{ha}^{-1}$ in middle taiga and $4 \mathrm{tC} \cdot \mathrm{ha}^{-1}$ in southern taiga during an average fire year; $53 \mathrm{tC} \cdot \mathrm{ha}^{-1}$ and $6 \mathrm{tC} \cdot \mathrm{ha}^{-1}$, respectively, in more severe fire years, based on the above estimates. Alternatively, using the simulated biomass that is removed from the simulation following a fire, we estimate that in southern taiga carbon emissions during the second half of the 21st century will be double the historical amount. This is an underestimate, because the carbon-rich organic floor is not considered in this calculation.

Although modules that simulate the spread of fire across the landscape exist (e.g., LANDIS [90]), they either require atmospheric data at the sub-daily time step for parameterization or couple to models that simulate vegetation as cohorts or plant functional types (not individual trees). SIBBORK-DISTURB-F presents a platform for investigation of the non-linear effects of climate on the fire disturbance regime and post-fire regeneration dynamics in the boreal ecosystem. Changes in stand structure or species composition will affect the carbon storage capacity of the ecosystem, as well as the way the ecosystem interacts with the atmosphere (through carbon exchange, albedo, radiation budget, etc.). Simulated forest structure and composition can be used to estimate carbon emissions due to fire disturbance and the role the boreal forests may play in the global carbon cycle in the 21st century and beyond. 
The SIBBORK vegetation model allows us to examine changes in vegetation structure and composition due to two concurrently changing regimes: climate and fire. Previous simulations estimated the disappearance of expositional larch forests on south-facing slopes in southern taiga by the year 2080 [47] and the replacement of the southern half of the Siberian boreal forest by steppe by the year 2080 [91], but those investigations only included the effect of climate on vegetation and did not consider disturbance. When concurrent effects of climate and fire are considered, our simulation studies show that significant portions of the forested landscape in mountainous southern taiga will transition to non-treed vegetation (steppe) by the year 2060. Upslope colonization is significantly slower than mortality from stress and fire within the historical range of these expositional larch forests. When only arboreal vegetation is considered and carbon emissions are computed based on above-ground biomass killed by the fires, our simulation shows that in the second half of the 21st century, the carbon emissions will double compared to the historical (1955-1990) emissions. Moreover, the steppe ecotone has a different fire regime with an annual fire return interval. The shift from the forest biome to a steppe changes the capacity of the landscape to sequester and store carbon, and the more frequent fire return interval changes its carbon emissions profile. These post-fire changes in vegetation can have further feedbacks to the regional climate, potentially increasing the drought risk due to decreased evapotranspiration from steppe compared to forest.

Furthermore, we applied SIBBORK in tandem with the new fire module DISTURB-F toward the investigation of how the middle taiga ecotone in central Siberia may be affected by the climate-driven changes in the fire regime. In our simulation, temperature-induced drought stress and repeat fires reduced the stand basal area by $20 \%$ during the 2050-2070 time frame and the biovolume by $50 \%$ by the year 2100. These are conservative estimates for changes in forest structure, because other disturbances, such as insect outbreaks, timber harvest and pathogens, are not considered in the simulation. Additionally, the linear extrapolation of observed warming trends may underestimate the climate changes this region is likely to experience in the near future.

These results are particularly timely due to the recent COP 21 meeting in Paris and the agreement to "cap" the global warming at $+2{ }^{\circ} \mathrm{C}$. Russia has been experiencing warming on the order of 2.5-times faster than the global average [22], and the continental locations in Siberia have not experienced concurrent increases in growing season precipitation. Extrapolation of the observed warming rates from the 1990-2014 time frame forward shows that central Siberia is likely to experience $+2{ }^{\circ} \mathrm{C}$ warming by the year 2040, while southern Siberia is likely to reach this state by the year 2050 (and on south-facing slopes, even sooner), compared to the historical (1955-1990) baseline [22,47]. Increases in temperature not accompanied by concurrent increases in precipitation result in greater Potential Evapotranspiration (PET) demands on vegetation, resulting in temperature-induced drought stress. Stressed or dry vegetation is easier to ignite and facilitates the spread of wildfires. In this manner, climatological changes alter vegetation health, structure and composition, which can result in the modification and potential intensification of the fire regime (return interval, intensity, extent). Furthermore, repeat burns often result in suppression of tree sapling regeneration, and what used to be a forested landscape shifts to grassland/meadow or steppe [28,59]. This biome shift, facilitated by changes in the fire regime, significantly alters the role of the landscape in the regional carbon cycle. Because Siberian forests cover millions of hectares and are experiencing accelerated change, alterations in the forest structure and composition and any biome shifts are likely to affect the global carbon cycle.

Large regions of southern taiga are likely to experience forest collapse and shift to a steppe ecotone within the next half century [91]. Increased tree mortality often results in standing dry snags, which contribute to the fuel load and may lead to more extensive spread of wildfires in the area. The carbon dynamics within the southern tree line ecotone are changing and are likely to shift more toward that region acting as a source of atmospheric carbon. The SIBBORK-DISTURB-F simulation model can be used to inform the mitigation and possible shifts between economy sectors that may become necessary to assure adaptation of the local populations and those that depend on the timber resources of southern taiga. 


\section{Conclusions}

Disturbances are an important element in shaping the landscape. With climatic changes, wildfire is playing an increasingly important role in the structure and carbon storage capacity of the Siberian boreal ecosystem. Although vegetation modeling using possible future climates has previously been used to estimate likely forest characteristics in the mid- and late-21st century (SibClim [85,86,91,92], SIBBORK [46], FAREAST [93]), most vegetation modeling studies did not consider the important disturbances of fire, logging and insect outbreaks. We present here a disturbance module DISTURB-F, which works in tandem with a spatially-explicit individual-based gap model that tracks the life of individual trees on a realistic landscape and exhibits emergent properties of increase in fire damage to the forest ecosystem upon the increase in temperature with or without changes in precipitation. The SIBBORK IBM with a fire subroutine captures the spatial and temporal variability of fire effects on the landscape. Fires of different intensities either result in complete mortality on the affected plot or kill the undergrowth and susceptible species, leaving tolerant larger trees standing. A reduction in stand density, crown closure and stand productivity is reproduced in the simulation, as is observed on the landscape [94]. The heterogeneity of stand structure is enhanced, especially following a crown fire, which corresponds to field observations [49]. The tandem SIBBORK-DISTURB-F simulation includes the parameterization for the effects of wildfire on tree stress, mortality and sapling establishment, showing different stand structure and composition for surviving stands, and different successional pathways in stands recovering from disturbances of different intensities. The inclusion of disturbance in forecasts of the role boreal forests may play in the global carbon budget in the near future is important, because with disturbance, the forest experiences significant shifts earlier than without. Coupling of the fire module to resolve the locations most likely to be affected by fires in the near future due to increased instances of drought may help direct observation or mitigation efforts. The ability to simulate multiple-plot gaps and changing environmental conditions renders SIBBORK a robust model for understanding the changing role of the boreal forest in the global carbon budget.

Acknowledgments: The authors are thankful to Whittlesey for programming consultation and helpful comments on an earlier version of this manuscript. This research was supported and funded by the Environmental Sciences Department at the University of Virginia, Virginia Space Grant Consortium Graduate Fellowship grant to K.B., NASA grant (NNX11AE39G) to H.H.S. and NASA grant (UM-3002295358) to the University of Michigan subcontracted to H.H.S. We kindly thank two anonymous reviewers for their helpful suggestions towards improving this manuscript.

Author Contributions: K.B., C.H. and H.H.S. conceived of and designed the experiments. C.H. developed the fire module. K.B. calibrated and tested the fire module. K.B. and C.H. performed the experiments. K.B. analyzed the data and wrote the paper. H.H.S. funded and supervised the project.

Conflicts of Interest: The authors declare no conflicts of interest. 


\section{Appendix}

Severny (middle taiga)

\section{Kyzyl \\ (southern taiga)}

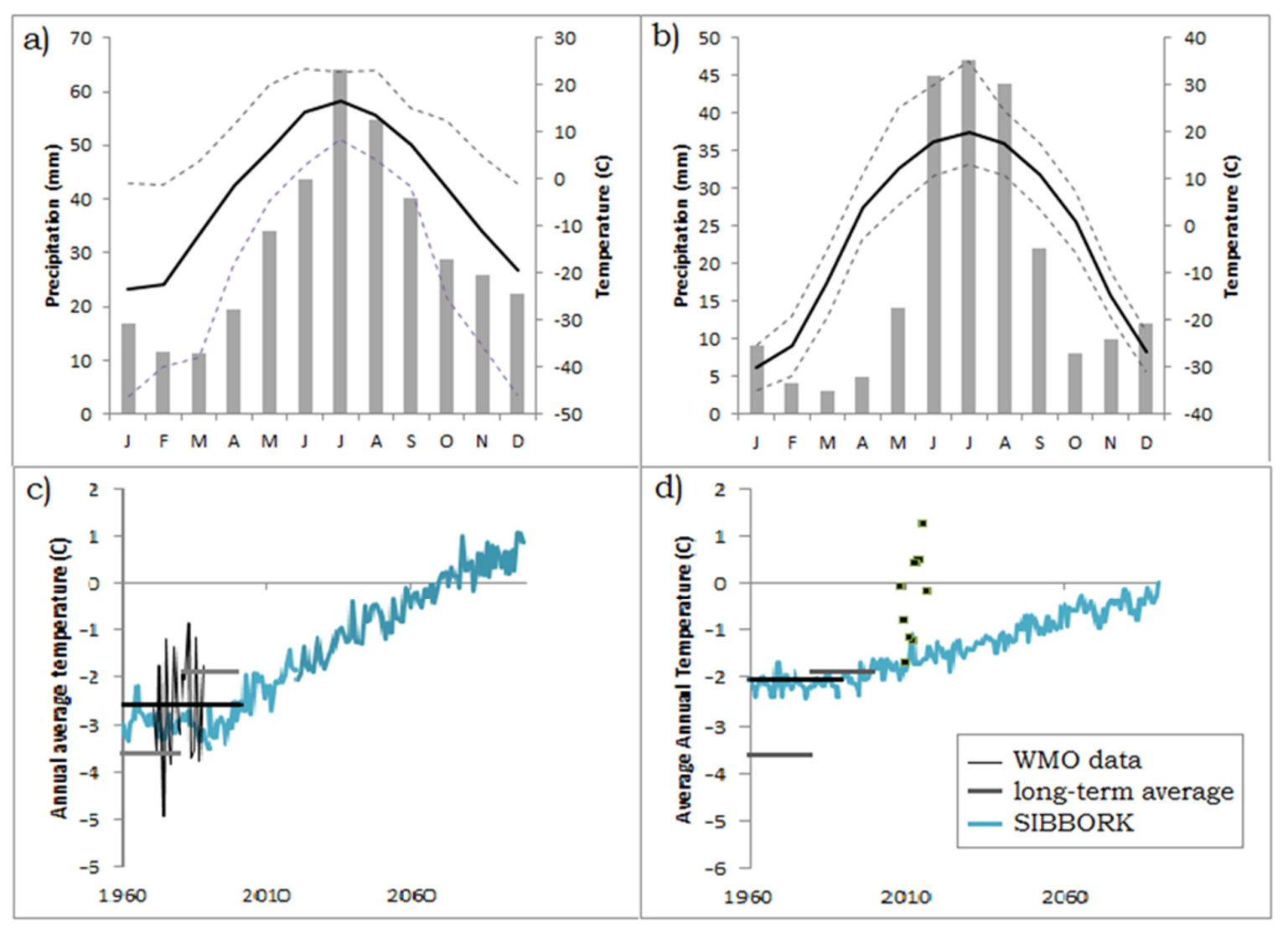

Figure A1. The simulation of climate in the SIBBORK model is driven by average monthly temperatures and the associated standard deviations, monthly maximum and minimum temperatures, and monthly precipitation sums. These values were obtained from the World Meteorological Organization records for stations (a) Ust'-Ilimsk (\#30117) and (b) Kyzyl (\#36096) for the 1960-1990 timeframe. Average annual temperature for the two simulated sites is shown in blue for the (c) Severny leskhoz and the (d) southern boreal boundary. These output values are compared to multidecadal averages for 1960-1980 and 1980-2000 timeframes, as well as to recent observations from 2008-2016. Simulated average annual temperatures are a conservative estimate obtained by extrapolating observed [22] seasonal trends for the regions.

\section{References}

1. Chapin, F.S., III; Oswood, M.W.; Van Cleve, K.; Viereck, L.A.; Verbyla, D.L. Alaska's Changing Boreal Forest; Oxford University Press: Oxford, UK, 2006.

2. Conard, S.G.; Solomon, A.M. Effects of wildland fire on regional and global carbon stocks in a changing environment. Dev. Environ. Sci. 2008, 8, 109-138.

3. Conard, S.G.; Ivanova, G.A. Wildfire in Russian boreal forests-Potential impacts of fire regime characteristics on emissions and global carbon balance estimates. Environ. Pollut. 1997, 98, 305-313. [CrossRef]

4. Goldammer, J.G.; Furyaev, V.V. Fire in ecosystems of boreal Eurasia: Ecological impacts and links to the global system. In Fire in Ecosystems of Boreal Eurasia; Springer: Dordrecht, The Netherlands, 1996; pp. 1-20.

5. De Groot, W.J.; Cantin, A.S.; Flannigan, M.D.; Soja, A.J.; Gowman, L.M.; Newbery, A. A comparison of Canadian and Russian boreal forest fire regimes. For. Ecol. Manag. 2013, 294, 23-34. [CrossRef] 
6. Conard, S.G.; Sukhinin, A.I.; Stocks, B.J.; Cahoon, D.R.; Davidenko, E.P.; Ivanova, G.A. Determining effects of area burned and fire severity on carbon cycling and emissions in Siberia. Clim. Chang. 2002, 55, 197-211. [CrossRef]

7. Gerard, F.; Plummer, S.; Wadsworth, R.; Sanfeliu, A.F.; Iliffe, L.; Balzter, H.; Wyatt, B. Forest fire scar detection in the boreal forest with multitemporal SPOT-VEGETATION data. IEEE Trans. Geosci. Remote Sens. 2003, 41, 2575-2585. [CrossRef]

8. Goetz, S.J.; Mack, M.C.; Gurney, K.R.; Randerson, J.T.; Houghton, R.A. Ecosystem responses to recent climate change and fire disturbance at northern high latitudes: Observations and model results contrasting northern Eurasia and North America. Environ. Res. Lett. 2007, 2, 045031. [CrossRef]

9. Kasischke, E.S.; French, N.H.F. Locating and estimating the areal extent of wildfires in Alaskan boreal forests using multiple-season AVHRR NDVI composite data. Remote Sens. Environ. 1995, 51, 263-275. [CrossRef]

10. Liu, H.; Randerson, J.T.; Lindfors, J.; Chapin, F.S. Changes in the surface energy budget after fire in boreal ecosystems of interior Alaska: An annual perspective. J. Geophys. Res. Atmos. 2005, 110, D13101. [CrossRef]

11. Bonan, G.B.; Shugart, H.H. Environmental Factors and Ecological Processes in Boreal Forests. Annu. Rev. Ecol. Syst. 1989, 20, 1-28. [CrossRef]

12. Furyaev, V.V. Fire ecology of Siberian boreal forests. In Fire in Ecosystems of Boreal Eurasia; Kluwer Academic Publishers: Dordrecht, The Netherlands, 1996; pp. 168-185.

13. Kharuk, V.I.; Ranson, K.J.; Dvinskaya, M.L.; Im, S.T. Wildfires in northern Siberian larch dominated communities. Environ. Res. Lett. 2011, 6, 045208. [CrossRef]

14. Korovin, G.N. Analysis of the distribution of forest fires in Russia. In Fire in Ecosystems of Boreal Eurasia; Goldammer, J.G., Furyaev, V.V., Eds.; Springer: Dordrecht, The Netherlands, 1996; pp. 112-128.

15. Valendik, E.N. Temporal and spatial distribution of forest fires in Siberia. In Fire in Ecosystems of Boreal Eurasia; Goldammer, J.G., Furyaev, V.V., Eds.; Springer: Dordrecht, The Netherlands, 1996; pp. 129-138.

16. Mollicone, D.; Eva, H.D.; Achard, F. Ecology: Human role in Russian wild fires. Nature 2006, 440, 436-437. [CrossRef] [PubMed]

17. Gustafson, E.J.; Shvidenko, A.Z.; Sturtevant, B.R.; Scheller, R.M. Predicting global change effects on forest biomass and composition in south-central Siberia. Ecol. Appl. 2010, 20, 700-715. [CrossRef] [PubMed]

18. Fosberg, M.A.; Stocks, B.J.; Lynham, T.J. Risk analysis in strategic planning: Fire and climate change in the boreal forest. In Fire in Ecosystems of Boreal Eurasia; Goldammer, J.G., Furyaev, V.V., Eds.; Springer: Dordrecht, The Netherlands, 1996; pp. 495-504.

19. Kharuk, V.I.; Dvinskaya, M.L.; Ranson, K.J. The spatiotemporal pattern of fires in northern Taiga larch forests of central Siberia. Russ. J. Ecol. 2005, 36, 302-311. (In Russian) [CrossRef]

20. Balzter, H.; Gerard, F.F.; George, C.T.; Rowland, C.S.; Jupp, T.E.; McCallum, I.; Shvidenko, A.; Nilsson, S.; Sukhinin, A.; Onuchin, A.; et al. Impact of the Arctic Oscillation pattern on interannual forest fire variability in Central Siberia. Geophys. Res. Lett. 2005, 32, L14709. [CrossRef]

21. Groisman, P.Y.; Sherstyukov, B.G.; Razuvaev, V.N.; Knight, R.W.; Enloe, J.G.; Stroumentova, N.S.; Whitfield, P.H.; Forland, E.; Hannsen-Bauer, I.; Tuomenvirta, H.; et al. Potential forest fire danger over Northern Eurasia: Changes during the 20th century. Glob. Planet. Chang. 2007, 56, 371-386. [CrossRef]

22. Gruza, G.V.; Bardin, M.Y.; Rankova, E.Y.; Rocheva, E.V.; Platova, T.V.; Samokhina, O.F.; Egorov, V.I.; Afanas'ev, A.M.; Paramonov, S.G.; Alekseev, G.V.; et al. A Report on Climate Features on the Territory of the Russian Federation in 2014. Moscow, Russia, 2015. Available online: http:/ / www.meteorf.ru (accessed on 27 March 2015). (In Russian)

23. Groisman, P.; Soja, A.J. Ongoing climatic change in Northern Eurasia: Justification for expedient research. Environ. Res. Lett. 2009, 4, 045002. [CrossRef]

24. Rylkov, V.F. Forest fires in the eastern Trans-Baikal Region and elimination of their consequences. In Fire in Ecosystems of Boreal Eurasia; Goldammer, J.G., Furyaev, V.V., Eds.; Springer: Dordrecht, The Netherlands, 1996; pp. 219-226.

25. Cvetkov, P.A. Determination of fire danger in Siberian forests. Lesn. Khozaistvo 2002, 5, 43-45. (In Russian)

26. Wirth, C. Fire regime and tree diversity in boreal forests: Implications for the carbon cycle. In Forest Diversity and Function; Springer: Berlin/Heidelberg, Germany, 2005; pp. 309-344.

27. Pleshikov, F.I.; Ryzhkova, V.A. Ecological Estimation of Forest Succession Patterns in Central Angara Region. In Fire in Ecosystems of Boreal Eurasia; Goldammer, J.G., Furyaev, V.V., Eds.; Springer: Dordrecht, The Netherlands, 1996; pp. 393-403. 
28. Ivanova, G.A.; Ivanov, V.A.; Kukavskaya, E.A.; Soja, A.J. The frequency of forest fires in Scots pine stands of Tuva, Russia. Environ. Res. Lett. 2010, 5, 015002. [CrossRef]

29. Kukavskaya, E.A.; Buryak, L.V.; Ivanova, G.A.; Conard, S.G.; Kalenskaya, O.P.; Zhila, S.V.; McRae, D.J. Influence of logging on the effects of wildfire in Siberia. Environ. Res. Lett. 2013, 8, 045034. [CrossRef]

30. Soja, A.J.; Tchebakova, N.M.; French, N.H.; Flannigan, M.D.; Shugart, H.H.; Stocks, B.J.; Sukhinin, A.I.; Parfenova, E.I.; Chapin, F.S., III. Climate-induced boreal forest change: Predictions versus current observations. Glob. Planet. Chang. 2007, 56, 274-296. [CrossRef]

31. Belov, S.V. Forest Pyrology; Leningrad Forest Academy of the USSR: St. Petersburg, Russia, 1976. (In Russian)

32. Gromtsev, A. Natural disturbance dynamics in the boreal forests of European Russia: A review. Silv. Fenn. 2002, 36, 41-55. [CrossRef]

33. Buryak, L.V.; Kalenskaya, O.P.; Tolmachev, A.V.; Yankovskii, R.V. Forest fires and their after-effects in the Sushensky Bor National Park. Lesn. Khozyaistvo 2009, 3, 37-39. (In Russian)

34. Viereck, L.A.; Van Cleve, K.; Dyrness, C.T. Forest ecosystem distribution in the taiga environment. In Forest Ecosystems in the Alaskan Taiga; Springer: New York, NY, USA, 1986; pp. 22-43.

35. Johnstone, J.F.; Chapin, F.S., III; Foote, J.; Kemmett, S.; Price, K.; Viereck, L. Decadal observations of tree regeneration following fire in boreal forests. Can. J. For. Res. 2004, 34, 267-273. [CrossRef]

36. Buryak, L.V.; Sukhinin, A.I.; Kalenskaya, O.P.; Ponomarev, E.I. Effects of fires in ribbon-like pine forests of southern Siberia. Sib. Ecol. J. 2011, 18, 331-339. (In Russian) [CrossRef]

37. Randerson, J.T.; Liu, H.; Flanner, M.G.; Chambers, S.D.; Jin, Y.; Hess, P.G.; Pfister, G.; Mack, M.C.; Treseder, K.K.; Welp, L.R.; et al. The impact of boreal forest fire on climate warming. Science 2006, 314, 1130-1132. [CrossRef] [PubMed]

38. Kharuk, V.I.; Ranson, K.J.; Oskorbin, P.A.; Im, S.T.; Dvinskaya, M.L. Climate induced birch mortality in Trans-Baikal lake region, Siberia. For. Ecol. Manag. 2013, 289, 385-392. [CrossRef]

39. Kharuk, V.I.; Im, S.T.; Oskorbin, P.A.; Petrov, I.A.; Ranson, K.J. Siberian pine decline and mortality in southern Siberian mountains. For. Ecol. Manag. 2013, 310, 312-320. [CrossRef]

40. Krankina, O.N.; Dixon, R.K. Forest management options to conserve and sequester terrestrial carbon in the Russian Federation. World Resour. Rev. 1994, 6, 88-101.

41. Krankina, O.N.; Harmon, M.E.; Winjum, J.K. Carbon storage and sequestration in the Russian forest sector. Ambio Stockh. 1996, 25, 284-288.

42. Krankina, O.N.; Houghton, R.A.; Harmon, M.E.; Hogg, E.H.; Butman, D.; Yatskov, M.; Huso, M.; Treyfeld, R.F.; Razuvaev, V.N.; Spycher, G. Effects of climate, disturbance, and species on forest biomass across Russia. Can. J. For. Res. 2005, 35, 2281-2293. [CrossRef]

43. Kurz, W.A.; Apps, M.J.; Stocks, B.J.; Volney, W.J.A. Global Climate Change: Disturbance Regimes and Biospheric Feedbacks of Temperate and Boreal Forests; Oxford University Press: New York, NY, USA, 1995; pp. 119-133.

44. Kurz, W.A.; Apps, M.J. A 70-year retrospective analysis of carbon fluxes in the Canadian forest sector. Ecol. Appl. 1999, 9, 526-547. [CrossRef]

45. Milakovsky, B.; Frey, B.; James, T. Carbon dynamics in the boreal forest. In Managing Forest Carbon in a Changing Climate; Springer: Dordrecht, The Netherlands, 2012; pp. 109-135.

46. Brazhnik, K.; Shugart, H.H. SIBBORK: A new spatially-explicit gap model for boreal forest. Ecol. Model. 2016, 320, 182-196. [CrossRef]

47. Brazhnik, K.; Shugart, H.H. 3D simulation of boreal forests: Structure and dynamics in complex terrain and in a changing climate. Environ. Res. Lett. 2015, 10, 105006. [CrossRef]

48. Gorbachev, V.N.; Popova, E.P. Fires and soil formation. In Fire in Ecosystems of Boreal Eurasia; Goldammer, J.G., Furyaev, V.V., Eds.; Springer: Dordrecht, The Netherlands, 1996; pp. 331-336.

49. Sannikov, S.N.; Goldammer, J.G. Fire ecology of pine forests of northern Eurasia. In Fire in Ecosystems of Boreal Eurasia; Goldammer, J.G., Furyaev, V.V., Eds.; Springer: Dordrecht, The Netherlands, 1996; pp. 151-167.

50. Sukhinin, A.I.; Ivanov, V.V.; Ponomarev, E.I.; Slinkina, O.A.; Cherepanov, A.V.; Pavlichenko, E.A.; Romasko, V.Y.; Miskiv, S.I. The 2002 fire season in the Asian part of the Russian Federation: A view from space. Int. For. Fire News 2002, 28, 18-28.

51. Kukavskaya, E.; Buryak, L.; Ivanova, G.; Kalenskaya, O.; Bogorodskaya, A.; Zhila, S.; McRae, G.; Conard, S. Logging and Fire Effects in Siberian Boreal Forests. In AGU Fall Meeting Abstracts; American Geophysical Union: San Francisco, CA, USA, 2013; Volume 1, p. 859. 
52. Yevdokimenko, M.D. Fire-induced transformations in the productivity of light coniferous stands of the Trans-Baikal region and Mongolia. In Fire in Ecosystems of Boreal Eurasia; Goldammer, J.G., Furyaev, V.V., Eds.; Springer: Dordrecht, The Netherlands, 1996; pp. 211-218.

53. Furyaev, V.V.; Furyaev, E.A. Pyrological properties of Pinus sylvestris in Central Siberia. Conifers Boreal Zone 2008, 25, 103-108. (In Russian)

54. Prentice, I.C.; Sykes, M.T.; Cramer, W. A simulation model for the transient effects of climate change on forest landscapes. Ecol. Model. 1993, 65, 51-70. [CrossRef]

55. Ivanova, G.A.; Ivanov, V.A. Fire regimes in Siberian forests. Int. For. Fires News 2005, 32, 67-69.

56. Furyaev, V.V.; Pleshikov, F.I.; Zlobin, L.P.; Furyaev, E.A. Transformation of structure and ecological function of forests under the influence of fire in central Siberia forestry. Lesovedenie 2004, 6, 50-57. (In Russian)

57. Clark, J.S.; Richard, P.J.H. The role of paleofire in boreal and other cool-coniferous forests. In Fire in Ecosystems of Boreal Eurasia; Goldammer, J.G., Furyaev, V.V., Eds.; Springer: Dordrecht, The Netherlands, 1996; pp. 65-89.

58. Furyaev, V.V.; Vaganov, E.A.; Tchebakova, N.M.; Valendik, E.N. Effects of fire and climate on successions and structural changes in the Siberian boreal forest (Russian Federation). Eurasian J. For. Res. 2001, 2, 1-15.

59. Buryak, L.V.; Sukhinin, A.I.; Moskal'chenko, S.A. Effect of fires on forest regeneration in the lower Angara region. Lesovedenie 2009, 5, 17-23.

60. Kukavskaya, E.A.; Soja, A.J.; Petkov, A.P.; Ponomarev, E.I.; Ivanova, G.A.; Conard, S.G. Fire emissions estimates in Siberia: Evaluation of uncertainties in area burned, land cover, and fuel consumption. Can. J. For. Res. 2012, 43, 493-506. [CrossRef]

61. Malevsky-Malevich, S.P.; Molkentin, E.K.; Nadyozhina, E.D.; Shklyarevich, O.B. An assessment of potential change in wildfire activity in the Russian boreal forest zone induced by climate warming during the twenty-first century. Clim. Chang. 2008, 86, 463-474. [CrossRef]

62. Stolbovoi, V.; McCallum, I. CD-ROM Land Resources of Russia; International Institute for Applied Systems Analysis and the Russian Academy of Science: Laxenburg, Austria, 2002.

63. National Climate Data Center (NCDC). Global Synoptic Climatology Network C the former USSR Version 1.0; NOAA National Climatic Data Center: Asheville, NC, USA, 2005.

64. National Climate Data Center (NCDC). Daily and Sub-Daily Precipitation for the Former USSR Version 1.0; NOAA National Climatic Data Center: Asheville, NC, USA, 2005.

65. Tchebakova, N.M.; Parfenova, E.I. Prediction of forest shifts under climate change at the end of the 20th century in Central Siberia. Comput. Technol. 2006, 11, 77-86. (In Russia)

66. METI and NASA Release Version 2 ASTER Global DEM. U.S. Geological Survey/NASA LP DAAC, 2011. Available online: https:/ /asterweb.jpl.nasa.gov/gdem.asp (accessed on 13 November 2013).

67. Polikarpov, N.P.; Tchebakova, N.M.; Nazimova, D.I. Climate and Mountain Forests of Siberia; Nauka Publishing House: Novosibirsk, Russia, 1986. (In Russian)

68. Irkutsk Oblast Forest Report (2013). Available online: irkobl.ru/sites/alh/documents/lesplan/lesplan1.pdf (accessed on 22 July 2015).

69. Gerasimov, I.P. Central Siberia; Nauka Publishing House: Moscow, Russia, 1964. (In Russian)

70. Goldammer, J.G.; Stocks, B.J. Eurasian perspective of fire: Dimension, management, policies, and scientific requirements. In Fire, Climate Change, and Carbon Cycling in the Boreal Forest; Springer: New York, NY, USA, 2000; pp. 49-64.

71. Goldammer, J.G.; Stocks, B.J.; Sukhinin, A.I.; Ponomarev, E. Current fire regimes, impacts and the likely changes-II: Forest Fires in Russia-Past and Current Trends. In Vegetation Fires and Global Change: Challenges for Concerted International Action; A White Paper directed to the United Nations and International Organizations; Global Fire Monitoring Center: Kessel, Germany, 2013; pp. 51-78.

72. Isaev, A.S.; Korovin, G.N.; Bartalev, S.A.; Ershov, D.V.; Janetos, A.; Kasischke, E.S.; Shugart, H.H.; French, N.H.F.; Orlick, B.E.; Murphy, T.L. Using remote sensing to assess Russian forest fire carbon emissions. Clim. Chang. 2002, 55, 235-249. [CrossRef]

73. Samoilova, G.S. Types of Landscapes in Mountains of Southern Siberia; Neklyudova, M.P., Ed.; Moscow State University Press: Moscow, Russia, 1973. (in Russian)

74. Chytry, M.; Danihelka, J.; Kubesova, S.; Lustyk, P.; Ermakov, N.; Hajek, M.; Hajkova, P.; Koci, M.; Otypkova, Z.; Rolecek, J.; et al. Diversity of forest vegetation across a strong gradient of climatic continentality: Western Sayan Mountains, southern Siberia. Plant Ecol. 2008, 196, 61-83. [CrossRef] 
75. Chlachula, J.; Sukhova, M.G. Regional manifestations of present climate change in the Altai, Siberia. Int. Proc. Chem. Biol. Environ. Eng. Environ. Eng. Appl. 2011, 17, 134-139.

76. Gruza, G.V.; Rankova, E.Y.; Razuvaev, V.N.; Bulygina, O.N. Indicators of climatic change for the Russian federation. Clim. Chang. 1999, 42, 219-242. [CrossRef]

77. Krylov, A.; McCarty, J.L.; Potapov, P.; Loboda, T.; Tyukavina, A.; Turubanova, S.; Hansen, M.C. Remote sensing estimates of stand-replacement fires in Russia, 2002-2011. Environ. Res. Lett. 2014, 9, 105007. [CrossRef]

78. Federal Forest Agency. The State and Use of Russian Federation Forests-Report for 2012. Available online: www.rosleshoz.gov.ru (accessed on 14 August 2015).

79. Giglio, L.; Loboda, T.; Roy, D.P.; Quayle, B.; Justice, C.O. An active-fire based burned area mapping algorithm for the MODIS sensor. Remote Sens. Environ. 2009, 113, 408-420. [CrossRef]

80. McRae, D.J.; Conard, S.G.; Ivanova, G.A.; Sukhinin, A.I.; Baker, S.P.; Samsonov, Y.N.; Blake, T.W.; Ivanov, V.A.; Ivanov, A.V.; Churkina, T.V.; et al. Variability of fire behavior, fire effects, and emissions in Scotch pine forests of Central Siberia. Mitig. Adapt. Strateg. Glob. Chang. 2006, 11, 45-74. [CrossRef]

81. Groisman, P.Y.; Sun, B.; Vose, R.S.; Lawrimore, J.H.; Whitfield, P.H.; Førland, E.; Hanssen-Bauer, I.; Serreze, M.C.; Razuvaev, V.N.; Alekseev, G.V. Contemporary climate changes in high latitudes of the Northern Hemisphere: Daily time resolution. In Proceeding of 14th AMS Symposium on Global Change and Climate Variations, Long Beach, CA, USA, 11 February 2013; p. 10.

82. Kasischke, E.S.; Hyer, E.J.; French, N.H.F.; Sukhinin, A.I.; Hewson, J.H.; Stocks, B.J. Carbon emissions from boreal forest fires: 1996 to 2002. Glob. Biogeochem. Cycles 2004, 19, GB1012.

83. Kukavskaya, E.; Soja, A.; Buryiak, L.; Tchebakova, N.; Parfenova, E.; Konzai, V.; Ivanova, G.; Sukhinin, A.; Kalenskaya, O.; Stackhouse, P., Jr.; et al. Climate-induced change in fire regimes in Tyva. In Abstract GC33A-0934 Presented at 2010 Fall Meeting; AGU: San Francisco, CA, USA, 2010.

84. Soja, A.J.; Sukhinin, A.I.; Cahoon, D.R., Jr.; Shugart, H.H.; Stackhouse, P.W., Jr. AVHRR-derived fire frequency, distribution and area burned in Siberia. Int. J. Remote Sens. 2004, 25, 1939-1960. [CrossRef]

85. Monserud, R.A.; Tchebakova, N.M. A vegetation model for the Sayan Mountains, southern Siberia. Can. J. For. Res. 1996, 26, 1055-1068. [CrossRef]

86. Tchebakova, N.M. Possible Transformation of Vegetation Cover in Siberia for Different Climate Change Scenarios. Doctorate Thesis, Sukachev Institute of Forestry, Krasnoyarsk, Russia, 2006. (In Russian)

87. Ishutin, Y.N. Forest Regeneration Post Burns in Ribbon Forests of Altaj; Altaj University Press: Barnaul, Russia, 2004.

88. Nikolov, N.; Helmisaari, H. Silvics of the circumpolar boreal forest tree species. In A Systems Analysis of the Global Boreal Forest; Shugart, H.H., Leemans, R., Bonan, G.B., Eds.; Cambridge University Press: Cambridge, UK, 1992; pp. 9-84.

89. Shvidenko, A.Z.; Nilsson, S. Fire and the carbon budget of Russian forests. In Fire, Climate Change, and Carbon Cycling in the Boreal Forest; Springer: New York, NY, USA, 2000; pp. 289-311.

90. Scheller, R.M.; Domingo, J.B. LANDIS-II Base Fire v3.0 Extension User Guide; University of Wisconsin: Madison, WI, USA, 2012.

91. Tchebakova, N.M.; Parfenova, E.I.; Soja, A.J. Potential climate-induced vegetation change in Siberia in the twenty-first century. In Environmental Change in Siberia; Springer: Dordrecht, The Netherlands, 2010; pp. 67-82.

92. Tchebakova, N.M.; Parfenova, E.; Soja, A.J. The effects of climate, permafrost and fire on vegetation change in Siberia in a changing climate. Environ. Res. Lett. 2009, 4, 045013. [CrossRef]

93. Xiaodong, Y.; Shugart, H.H. FAREAST: A forest gap model to simulate dynamics and patterns of eastern Eurasian forests. J. Biogeogr. 2005, 32, 1641-1658. [CrossRef]

94. Sannikov, S.N. Forest Fires as Evolutionary-Ecological Factor of Regeneration of Pine Populations in the Transural Region. Goren. Pozhary Lesu 1973, 236-277. (In Russian)

(C) 2017 by the authors. Licensee MDPI, Basel, Switzerland. This article is an open access article distributed under the terms and conditions of the Creative Commons Attribution (CC BY) license (http:/ / creativecommons.org/licenses/by/4.0/). 